Short-Term Effects of the 2008 High-Flow Experiment on Macroinvertebrates in Colorado River Below Glen Canyon Dam, Arizona

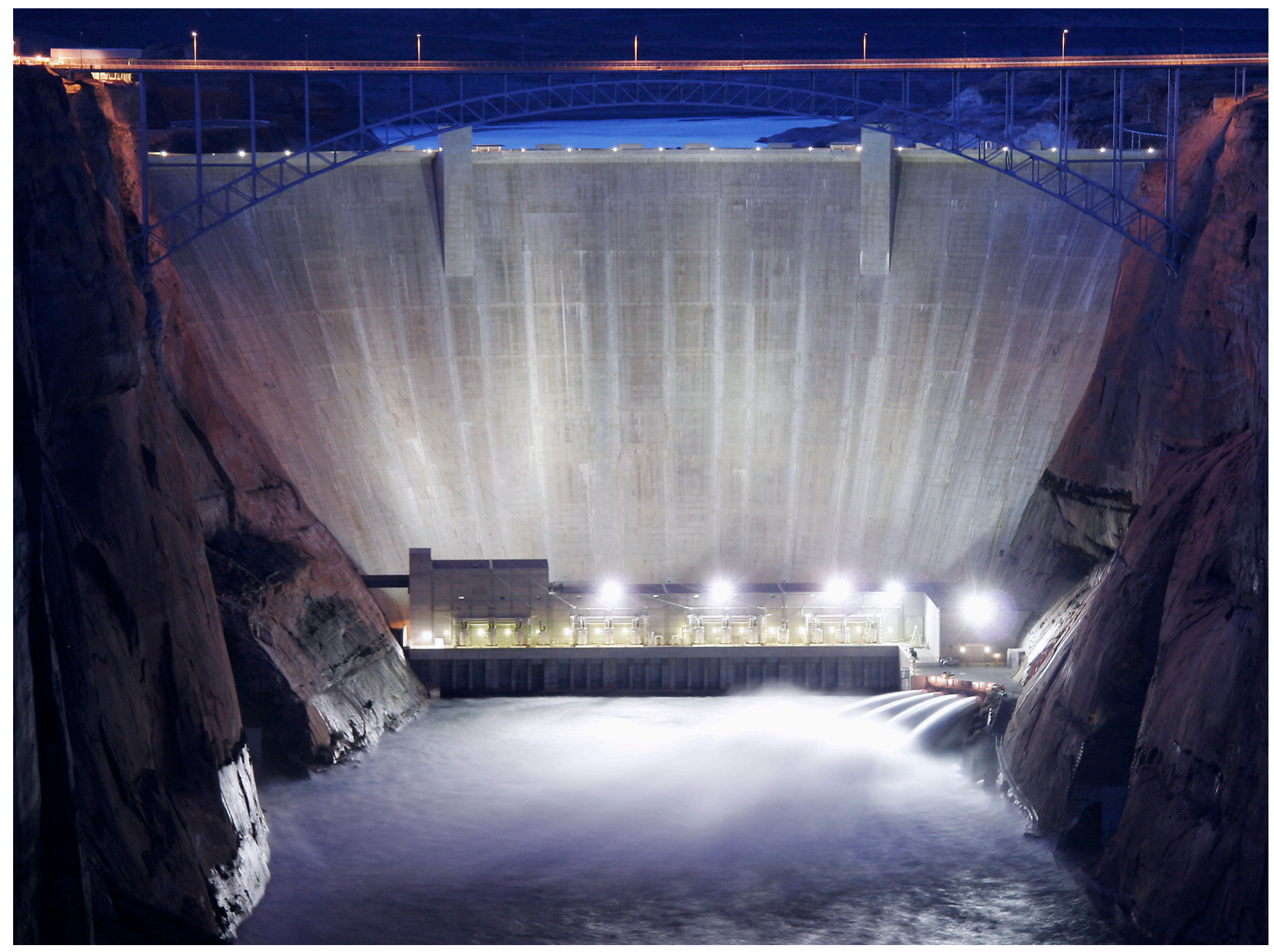

Open-File Report 2010-1031 
Cover: Glen Canyon Dam releases high flows of Colorado River water on the night of March 6, 2008. (Photograph courtesy of T. Ross Reeve, Bureau of Reclamation.) 


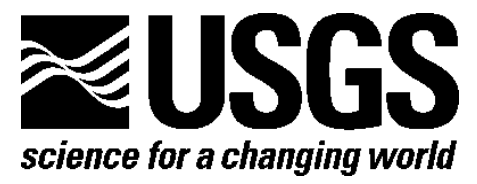

In cooperation with Cary Institute for Ecosystem Studies, Montana State University, Loyola University-Chicago, University of Wyoming, and Idaho State University

\section{Short-Term Effects of the 2008 High-Flow Experiment on Macroinvertebrates in Colorado River Below Glen Canyon Dam, Arizona}

By Emma J. Rosi-Marshall, Theodore A. Kennedy, Dustin W. Kincaid, Wyatt F. Cross, Holly A.W. Kelly, Kathrine A. Behn, Tyler White, Robert O. Hall, Jr., and Colden V. Baxter

Open-File Report 2010-1031

U.S. Department of the Interior

U.S. Geological Survey 


\section{U.S. Department of the Interior \\ KEN SALAZAR, Secretary}

\section{U.S. Geological Survey \\ Marcia K. McNutt, Director}

U.S. Geological Survey, Reston, Virginia 2010

For product and ordering information:

World Wide Web: http://www.usgs.gov/pubprod

Telephone: 1-888-ASK-USGS

For more information on the USGS-the Federal source for science about the Earth,

its natural and living resources, natural hazards, and the environment:

World Wide Web: http://www.usgs.gov

Telephone: 1-888-ASK-USGS

Suggested citation:

Rosi-Marshall, E.J., Kennedy, T.A., Kincaid, D.W., Cross, W.F., Kelly, H.A.W., Behn. K.A., White, T., Hall, R.O., Jr., and Baxter, C.V., 2010, Short-term effects of the 2008 high-flow experiment on macroinvertebrates in the Colorado River below Glen Canyon Dam, Arizona: U.S. Geological Survey Open-File Report 2010-1031, 28 p.

Any use of trade, product, or firm names is for descriptive purposes only and does not imply endorsement by the U.S. Government.

Although this report is in the public domain, permission must be secured from the individual copyright owners to reproduce any copyrighted material contained within this report. 


\section{Contents}

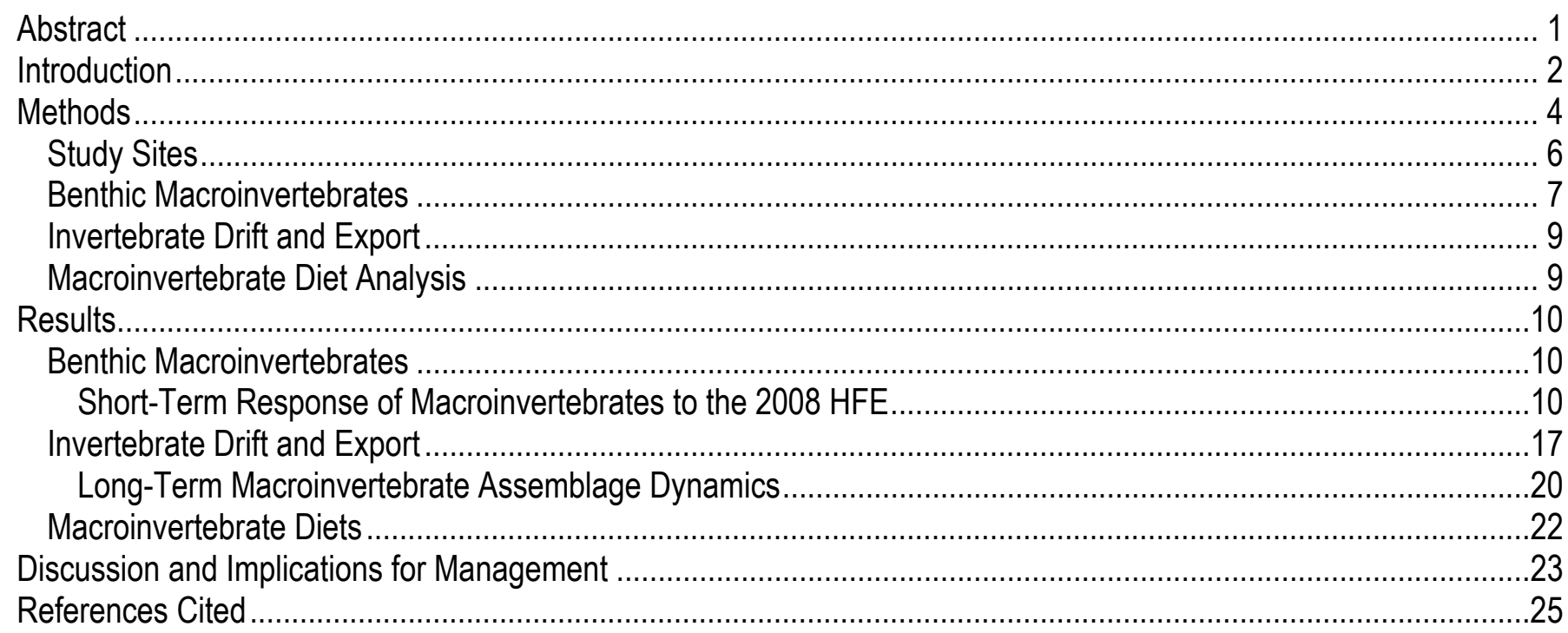

\section{Figures}

1. Mean daily discharge in the Colorado River at Lees Ferry for the period encompassing the high-flow experiment in 2008 and 1996.

2. Map of the Colorado River in Grand Canyon, showing locations of the three reaches that were sampled as part of this study

3. Bar graphs showing macroinvertebrate biomass measured in $\mathrm{AFDM} / \mathrm{m}^{2}$ and relative taxa composition in the three dominant habitat types at the three study sites on the Colorado River in Arizona

4. Line graphs showing the change in total benthic macroinvertebrate biomass measured in $\mathrm{g}$ or $\mathrm{mg} \mathrm{AFDM} / \mathrm{m}^{2}$ at three study sites following the March 2008 high-flow experiment.

5. Line graphs showing changes in biomass in benthic macroinvertebrate taxa measured in $\mathrm{AFDM} /$ at river mile 0 following the March 2008 high-flow experiment

6. Changes in biomass measured in $\mathrm{mg} \mathrm{AFDM} / \mathrm{m}^{2}$ at river mile 62 following the March 2008 high-flow experiment.

7. Line graphs showing change in biomass measured in $\mathrm{mg} A F D M / \mathrm{m}^{2}$ of individual taxa at river mile 225 after the March 2008 high-flow experiment.

8. Export of benthic invertebrates in drift from river mile 0 on the Colorado River during the March 2008 highflow experiment

9. Concentrations of invertebrate taxa in the drift at river mile 0 along the Colorado River from August 2007 to December 2009

10. Bar graphs showing long-term macroinvertebrate assemblage dynamics at river mile 0 on the Colorado River

11. Bar graphs showing the percentage of diatoms in macroinvertebrate diets for $(A)$ Gammarus lacustris, $(B)$ Potamopyrgus antipodarum, and $(C)$ Simuliidae before and after the March 2008 high-flow experiment ...... 22 


\section{Tables}

1. Type and number of samples taken in each habitat type at the three sampling locations ……...................... 8

2. Invertebrate secondary production in milligrams of ash-free dry mass per meter squared per year in the Glen

Canyon section of the Colorado River, Ariz., between July 2006 and June 2009....................................... 20 


\title{
Short-Term Effects of the 2008 High-Flow Experiment on Macroinvertebrates in the Colorado River Below Glen Canyon Dam, Arizona
}

By Emma J. Rosi-Marshall1, 4, Theodore A. Kennedy², Dustin W. Kincaid ${ }^{1,4}$, Wyatt F. Cross ${ }^{3}$, Holly A.W. Kelly ${ }^{4}$, Kathrine A. Behn ${ }^{5}$, Tyler White ${ }^{4}$, Robert O. Hall, Jr. ${ }^{5}$, and Colden V. Baxter ${ }^{6}$

\begin{abstract}
Glen Canyon Dam has dramatically altered the physical environment (especially discharge regime, water temperatures, and sediment inputs) of the Colorado River. High-flow experiments (HFE) that mimic one aspect of the natural hydrograph (floods) were implemented in 1996, 2004, and 2008. The primary goal of these experiments was to increase the size and total area of sandbar habitats that provide both camping sites for recreational users and create backwaters (areas of stagnant flow in the lee of return-current eddies) that may be important as rearing habitat for native fish. Experimental flows might also positively or negatively alter the rainbow trout (Oncorhynchus mykiss) sport fishery in the clear tailwater reach below Glen Canyon Dam, Ariz., and native fish populations in downstream reaches (for example, endangered humpback chub, Gila cypha) through changes in available food resources.

We examined the short-term response of benthic macroinvertebrates to the March $2008 \mathrm{HFE}$ at three sites [river mile 0 (RM 0, 15.7 miles downriver from the dam), RM 62, and RM 225] along the Colorado River downstream from Glen Canyon Dam by sampling immediately before and then 1, 7, 14, and 30 days after the HFE. We selected these sites because of their importance to management; RM 0 has a valuable trout fishery, and RM 62 is the location of the largest population of the endangered humpback chub in the Grand Canyon. In addition to the short-term collection of samples, as part of parallel investigations, we collected 3 years of monthly (quarterly for RM 62) benthic macroinvertebrate samples that included 15 months of post-HFE data for all three sites, but processing of the samples is only complete for one site (RM 0). At RM 0, the HFE caused an immediate $1.75 \mathrm{~g} \mathrm{AFDM} / \mathrm{m}^{2}$ (expressed as grams ash-free dry mass, or AFDM) reduction of macroinvertebrate biomass that was driven by significant reductions in the biomass of the two dominant taxa in this reach-Potamopyrgus antipodarum (New Zealand mud snails) and Gammarus lacustris (scuds or side-swimmers) —and also biomass reductions of other common taxa (worms in the families Lumbricidae and Tubificidae). Invertebrate drift estimates during the HFE suggest that reductions in biomass of some taxa were because of export from the reach. Reductions in biomass of P. antipodarum and G. lacustris persisted at least 15 months after the HFE, when this study concluded, and coincided with a significant decline in

\footnotetext{
${ }^{1}$ Present affiliation: Cary Institute for Ecosystem Studies, Millbrook, New York.

${ }^{2}$ U.S. Geological Survey, Southwest Biological Science Center, Grand Canyon Monitoring and Research Center, Flagstaff, Arizona.

${ }^{3}$ Montana State University, Bozeman, Montana.

${ }^{4}$ Loyola University, Chicago, Illinois.

${ }^{5}$ University of Wyoming, Laramie, Wyoming.

${ }^{6}$ Idaho State University, Pocatello, Idaho.
} 
the annual production of these taxa: $P$. antipodarum production of 11 to $13 \mathrm{~g} \mathrm{AFDM} / \mathrm{m}^{2} / \mathrm{yr}$ in two preHFE years versus $2 \mathrm{~g} \mathrm{AFDM} / \mathrm{m}^{2} / \mathrm{yr}$ in the post-HFE year, and G. lacustris production of 7 to $8 \mathrm{~g}$ $\mathrm{AFDM} / \mathrm{m}^{2} / \mathrm{yr}$ in two pre-HFE years versus $3 \mathrm{~g}$ AFDM $/ \mathrm{m}^{2} / \mathrm{yr}$ in the post-HFE year. There were not changes in invertebrate feeding habits in response to the HFE, as our 3-year dataset of invertebrate diets indicated no substantial changes. Our long-term analysis of the composition of the drift indicates that because of a reduction in $P$. antipodarum in the drift relative to digestible taxa, the quality of the drift as a food resource for fishes increased. At downstream sites, total assemblage biomass did not decline, likely because assemblages were dominated by blackflies (Simulium arcticum), which were not affected by the HFE. Similar to RM 0, G. lacustris and Tubificidae had significantly lower biomass after the HFE at RM 62 and RM 225. Chironomids were also significantly lower following the flood at both downstream sites.

Our findings demonstrate that the effects of a HFE on invertebrates may persist up to at least 15 months in the clear tailwater below the dam, whereas in downstream reaches impacts were more short lived. If controlling the abundance of $P$. antipodarum is a goal of managers, our findings indicate that periodic HFEs on the order of every 2 to 3 years may be an effective strategy for meeting that goal. More frequent HFEs may cause a shift in the state of the benthic invertebrate assemblage of the tailwater reach towards lower overall invertebrate biomass but higher quality (that is, digestible) food resources that may benefit the trout population in this reach. The results of this study provide little evidence of a strong negative effect of the 2008 HFE on benthic macroinvertebrates at downstream sites in Grand Canyon that support native fish populations. In fact, the 2008 HFE potentially facilitated shifts in the quality of prey available to native species, but evaluation of this issue will depend on analysis of longer term datasets, as well as estimates of annual production and food web flows. The latter analyses are also required for the essential step of determining the extent to which fishes, native or nonnative, are food limited. The results of such analyses are forthcoming and, together with those presented here, will provide a thorough ecosystem-level assessment of this experiment and management actions being conducted by the Glen Canyon Dam Adaptive Management Program.

\section{Introduction}

Governments have constructed large dams on most rivers throughout the world that have caused dramatic changes to their natural flow regimes, including the loss of periodic flooding (Benke, 1990; Pringle and others, 2000; Nilsson and others, 2005). Flood control is frequently a stated goal of dam construction, along with other benefits to humans such as hydropower generation, water storage, and recreation. However, distortion of natural flow regimes has had many consequences for riverine ecosystems (Ward and Stanford, 1983; Poff and others, 1997; Poff and others, 2007). Bunn and Arthington (2002) summarized the changes that can be expected for river communities based on altered flow regimes associated with river regulation. For example, altered flow regimes change the physical template of these systems, which in turn can influence biota because aquatic species have often evolved life-history strategies to adapt to the annual flow regime. In addition, altered flow regimes can promote invasion success by nonnative species. Although there are numerous aspects of a natural flow regime, large floods, in particular, can shape the physical template of rivers and their biological communities (Poff and others, 1997). These communities include benthic invertebrates that play a critical role in energy transfer to fishes and can be sentinels of ecosystem changes like those induced by flow regulation (Allan and Castillo, 2007; Merritt and others, 2008). Flow regulation eliminates the seasonally dynamic characteristics of riverine habitats (Ligon and others, 1995), and the benthic invertebrate assemblages of regulated rivers are typically dominated by taxa that are tolerant of 
regulated flows and that may even outcompete native taxa that rely on periodic flooding (Armitage, 1976; Poff and Allan, 1995).

Experimental high-flow releases from dams that attempt to mimic floods were explored as a possible mitigation strategy below large impoundments to restore and maintain desired river ecosystem characteristics (Patten and others, 2001; Robinson and others, 2004; Williams, 2006). This strategy was used below numerous dams (Robinson and others, 2004), and in one case in Switzerland multiple floods were implemented over a number of years and changed the ecosystem state (including macroinvertebrate-assemblage composition) (Robinson and Uehlinger, 2008). High-flow experiments are only one aspect of the restoration of a natural flow regime (which include high flows (floods), low base flows, and high-pulse flows), and various aspects of a flow regime influence riverine ecosystem structure and function (see Richter and others, 2006). The magnitude, timing, and frequency of experimental high flows that allow for the maintenance or restoration of desired ecosystem structure and function will vary among river systems; adaptive management (Walters and Holling, 1990) provides an ideal framework for implementing, evaluating, and refining experimental high-flow hydrographs.

Glen Canyon Dam (GCD) on the Colorado River represents a dramatic example of the effects of regulation on a river ecosystem and is also the testing ground for an ambitious program of adaptive management experimentation. Constructed in 1963, GCD transformed the river by altering its flow, sediment, and temperature regimes (Blinn and Cole, 1991). The effects of GCD on the downstream physical template are well documented (see Schmidt and others, 2001). Historically, the Colorado River had high seasonal variability in temperature and discharge (Topping and others, 2003), had seasonally variable concentrations of suspended sediments, and at times was sediment laden (Wright and others, 2009). The reservoir upstream of GCD traps 93 percent of the sediment input that historically entered the Grand Canyon reach of the Colorado River, thus the downstream reach is sediment starved and prone to erosion. The lack of sediment has changed the benthic habitats (Schmidt and others, 2001). In addition, hypolimnetic releases from the reservoir have altered the thermal regime of the river. Before $\mathrm{GCD}$, temperatures ranged from 2 to $29^{\circ} \mathrm{C}$, whereas after GCD temperatures are a nearly constant 9 to $13^{\circ} \mathrm{C}$ (Wright and others, 2009).

The benthic macroinvertebrate communities have changed as a result of Glen Canyon Dam. In addition to changes in habitat, temperature, and flow regime, nonnative invertebrates and fishes were intentionally or accidentally introduced and became established in the system. In general, the flow regime of western U.S. rivers is an important driver of benthic macroinvertebrate communities (Konrad and others, 2008). Historically, the Colorado River in Glen and Grand Canyons supported a diverse macroinvertebrate assemblage (Musser, 1959; Edmunds, 1959) that was possibly similar to the diverse benthic communities found in the upstream reaches in the Green and Colorado Rivers (Haden and others, 2003), though this is not known for certain. Benthic communities in the tailwaters of GCD are dominated by filamentous algae (Cladophora glomerata) and associated epiphytic diatoms and an impoverished assemblage of invertebrates dominated by amphipods, oligochaetes, and Nearctic dipterans (Stevens and others, 1997). Farther downstream, the benthic communities are dominated by Nearctic dipterans and collector-gatherer midges (Stevens and others, 1997), and these sites are still seasonally influenced by tributary sediment and organic matter inputs, making them more similar to the pre-dam condition. The many physical and biological changes to the river and the impassable nature of GCD has coincided with the local extirpation of four native fishes and substantial declines in remaining four native fishes (Minckley and others, 2003). In addition, a productive rainbow trout (Oncorhynchus mykiss) fishery was established in Glen Canyon. Restoration of conditions favorable to native fishes, including maintenance of invertebrate taxa whose productivity contributes to the aquatic food base for fishes in general, is therefore a goal of adaptive management of flows through GCD. 
The Glen Canyon Dam Adaptive Management Program implemented high-flow experiments (HFEs) in the past (March 1996 and November 2004), but the response of benthic invertebrates was only assessed in association with the 1996 HFE. Research surrounding the 1996 HFE demonstrated that the high flows lowered primary producer and invertebrate biomass and that recovery occurred relatively rapidly (from between 1 to 7 months depending on the taxon; Shannon and others, 2001). However, Shannon and others (2001) stated, "it is not clear whether the rapid colonization of biota would have occurred without the high steady discharges and the extended period of high water clarity that followed the test flood." That is, the unusual period of high steady flows that occurred after the 1996 flood promoted recovery of invertebrate biomass. Thus, one aim of continued HFEs is to evaluate whether post-experiment flow conditions appear to mediate responses by the benthos. A goal of adaptive management is to "learn by doing" (Walters and Holling, 1990), and lessons learned from past HFE studies should inform subsequent efforts. Previous research examining the effects of HFEs on benthic communities of the Colorado River focused on static measures (such as algal biomass and invertebrate biomass) at a relatively coarse temporal scale (for example, monthly measurements following the flood). Therefore, previous monitoring lacked both the short-term perspective on dynamics of macroinvertebrates immediately following the HFE, as well as a long-term, continuous dataset to evaluate effects of the HFE at the scale of seasons or years. Examining both short- and long-term dynamics can offer insights into the mechanisms behind ecologically significant effects of management decisions (for example Vinson, 2001; Robinson and Uehlinger, 2008). In addition, although past studies did not evaluate changes in the diets of invertebrate consumers, mechanisms may become clearer when food-web linkages are actually evaluated, rather than inferred.

A challenge to adaptive management is that the ecosystem of concern frequently undergoes changes that set a new baseline for evaluating responses to management experiments, and one such change common to regulated rivers is invasion by nonnative species. Since the HFE conducted in 1996, a new nonnative species, the New Zealand mud snail (Potamopyrgus antipodarum), now dominates the biomass and production of the tailwater invertebrate assemblage below GCD (see Cross and others, in press). This invasive species is of concern because it dominates benthic invertebrate biomass and production and is an inefficient prey source for some fishes downstream of GCD, especially trout (Vinson and Baker, 2008). P. antipodarum reach high densities in systems with relatively stable flows (Hall and others, 2006); this species may be sensitive to flooding, but this response has not been explicitly examined in the Grand Canyon.

In March 2008, a third HFE was conducted at GCD. We examined the effects of this HFE on benthic macroinvertebrate biomass and drift. In the tailwater below GCD, as well as in two downstream reaches of the Colorado River in Grand Canyon, we assessed the presence of short-term responses through high-resolution sampling of macroinvertebrates on approximately 1, 7, 14, and 30 days after the HFE. We also evaluated the long-term effects of the HFE on invertebrate biomass, production, and drift in the clear tailwaters below GCD with a 3-year dataset of invertebrate biomass, production, diet, and drift data that included approximately 15 months of post-HFE data. Using this approach, we examined the degree to which the HFE affected the invertebrate assemblage (including the occurrence of New Zealand mud snails), invertebrate diets, and the potential availability of invertebrates as prey to fishes. In addition, we examined the effects of the HFE at finer temporal resolution and over a greater temporal extent than was accomplished for previous HFEs.

\section{Methods}

We conducted this study in association with the March 2008 HFE in the Colorado River downstream of GCD. The HFE began on March 5 and lasted approximately 60 hours, reaching a 
maximum discharge of about $1,200 \mathrm{~m}^{3} / \mathrm{s}$ (fig. 1). The peak discharge was slightly less than 3.5 times the mean maximum discharge of the previous 5 days (about $360 \mathrm{~m}^{3} / \mathrm{s}$ ) and was less than the pre-dam average peak discharge (fig. 1).

To assess effects of the HFE, we sampled macroinvertebrates in the benthos and the drift. To quantify any immediate response of benthic macroinvertebrates to the HFE, we sampled three study reaches located successively further downstream from GCD (fig. 2) 1 day before and approximately 1, 7, 14, and 30 days after the HFE. Dates of sampling differed slightly among the three study reaches because the HFE moved in a wave downstream from GCD. In addition to the short-term sampling surrounding the HFE, we made comparisons for the study reach immediately downstream of GCD using data on benthic invertebrate biomass and production that we collected as part of parallel investigations on a monthly basis over 3 years (2007-09), including 15 months after the HFE.

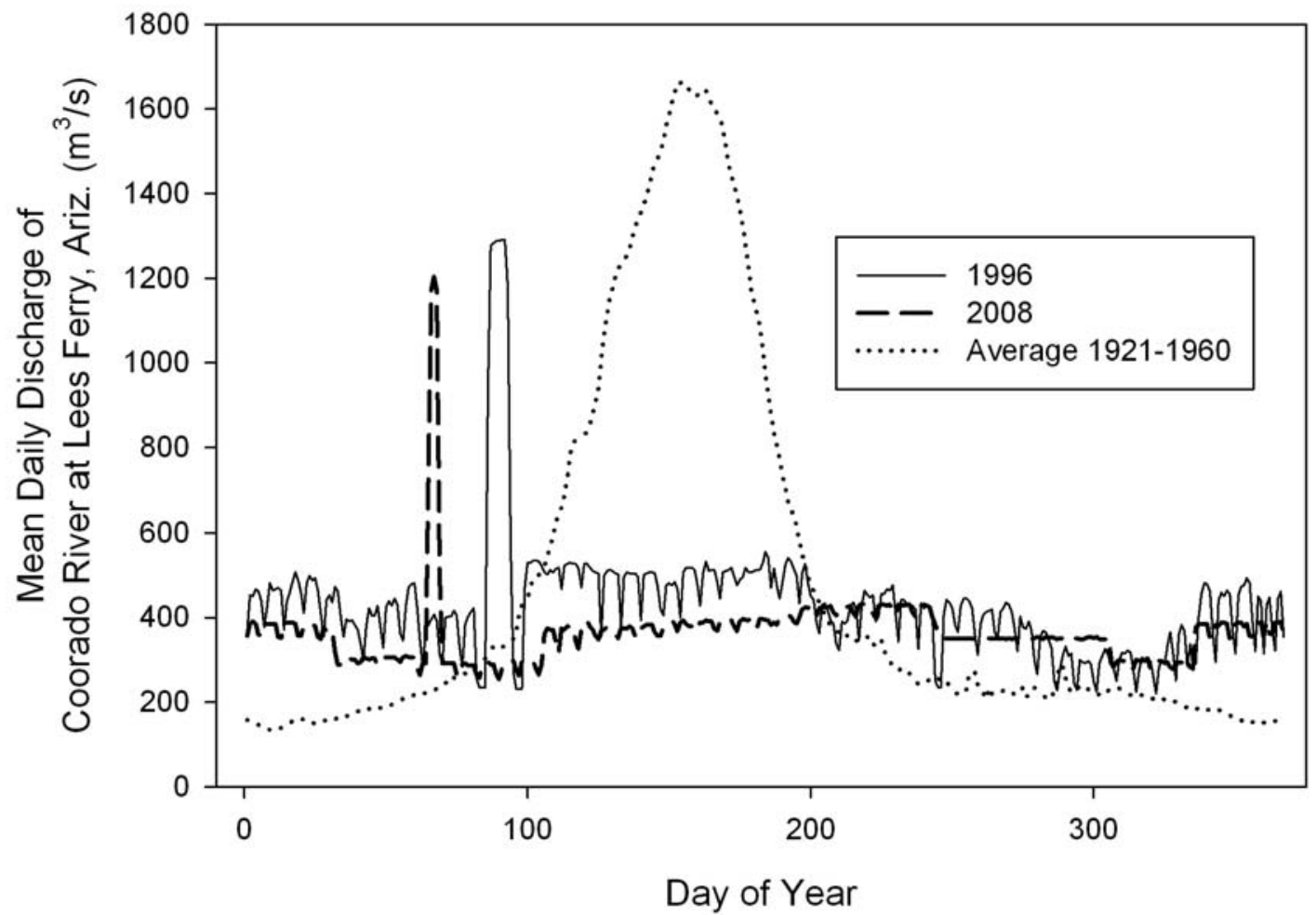

Figure 1. Mean daily discharge in the Colorado River at Lees Ferry (river mile 0, RM 0) for the period encompassing the high-flow experiment in 2008 (dashed line) and 1996 (solid line). Average hydrograph of the pre-dam Colorado River at Lees Ferry is also illustrated (dotted line). River mile is used to describe distance along the Colorado River in Grand Canyon: Lees Ferry is the starting point, as RM 0, with mileage measured for both upstream (-) and downstream directions. 


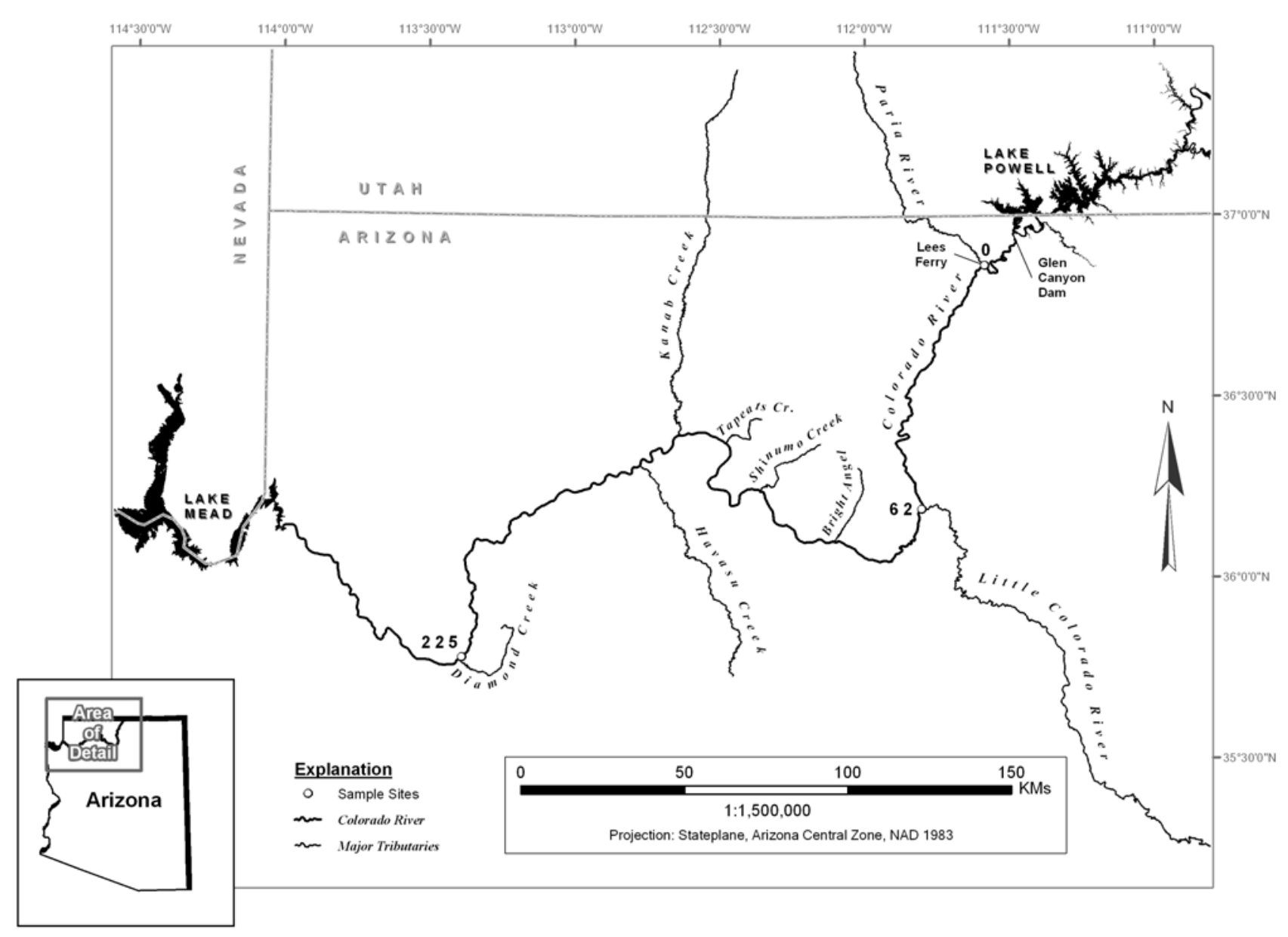

Figure 2. Map of the Colorado River in Grand Canyon, showing locations of the three reaches that were sampled as part of this study: river mile (RM) 0 (between Glen Canyon Dam and Lees Ferry), RM 62 (just below confluence with Little Colorado River), and RM 225 (just upriver of Diamond Creek). River mile is used to describe distance along the Colorado River in Grand Canyon: Lees Ferry is the starting point, as RM 0, with mileage measured for both upstream (-) and downstream directions.

\section{Study Sites}

By convention, river mile (RM) is used to describe distance along the Colorado River in Grand Canyon: Lees Ferry (located 15.7 miles downstream of Glen Canyon Dam) is the starting point, as RM 0 , with mileage measured for both upstream (-) and downstream directions. For this study, we sampled organic matter and invertebrates at three study reaches that were sufficiently long to capture geomorphic variability, but lengths were constrained by large rapids: (1) RM 0 (sampling occurred between RM -9.3 and RM -3.8), (2) RM 62, located just below the confluence with the Little Colorado River (sampling occurred between RM 62.0 and RM 65.6), and (3) RM 225 (sampling occurred between RM 223.7 and 225.9) (fig. 2). We selected these sites because of their importance to (1) management of the trout fishery at RM 0 and (2) the management of the endangered humpback chub (Gila cypha) at RM 62. RM 225 is the last site accessible in the Grand Canyon before the Colorado River enters Lake Mead. 
Between GCD and RM 0 there are no perennial tributaries, and nearly all of the river's discharge originates from the hypolimnion of Lake Powell by way of GCD. Discharge in this reach varies with the operations of the dam. Shifting hydroelectric power demands create daily fluctuations in discharge, whereas water distribution schedules yield interseasonal and interannual variation (Topping and others, 2003). At RM 62 and RM 225 the river is influenced by a number of tributaries that add discharge but especially contribute organic and inorganic material to the river and thereby increase suspended sediments and decrease light availability for benthic algae. The macroinvertebrate assemblages and the resources that support them at these three sites change longitudinally and seasonally (Stevens and others, 1997). The habitats of all study sites are dominated by fine-grained substrate habitats in depositional zones and hard substrates in cobble-gravel bars, cliff faces, and variably sized talus (Howard and Dolan, 1981).

\section{Benthic Macroinvertebrates}

We quantitatively sampled the dominant benthic habitats in the three study reaches 1 day before the HFE and approximately 1, 7, 14, and 30 days after the HFE. Habitat classes included cobble/gravel bars, talus/cliff faces, and fine-grained depositional zones. To sample the cobbles at RM 0, we used a Hess sampler (250- $\mu$ m mesh size, Wildlife Supply Company, Buffalo, N.Y.). At downstream sites, where a Hess sampler is not effective because the cobbles are embedded and large, we haphazardly selected a large cobble (always $>15 \mathrm{~cm}$ across), picked it up to minimize the loss of invertebrates (most taxa present in this river system commonly do not dislodge from rocks on removal as they are relatively sessile), scraped and washed all invertebrates from the rock into a bucket, and the contents of the bucket were washed onto a $250 \mu \mathrm{m}$ sieve. This method does not capture invertebrates dwelling in interstitial spaces, but because rocks are highly embedded at downstream sites, we predict that the number of interstitial invertebrates was minimal. We photographed the rock and used image analysis (ImagePro(C) to estimate its area. We sampled talus and cliff substrates using a battery-powered suction sampler equipped with a $250-\mu \mathrm{m}$ mesh. We collected 30 repeated intakes using the suction sampler, which represented $0.066 \mathrm{~m}^{2}$ of habitat. Depositional habitats were sampled using a Standard Ponar Dredge sampler $\left(0.052 \mathrm{~m}^{2}, 250-\mu \mathrm{m}\right.$ mesh). At all sites, we collected a total of 20 samples from depositional, cobble, and cliff faces or talus slopes (table 1). At all sites, we noted locations for the sampling patches (approximately 10 to $100 \mathrm{~m}^{2}$ ), marked them on a map, and we sampled the same habitat patch (approximately 10 to $100 \mathrm{~m}^{2}$ ) during each sampling period (note: we used these same sampling patches in the years before the HFE as part of our ongoing research project). In all cases, we preserved invertebrates in the field using 70 percent ethanol. In the laboratory, we separated samples into large $(>1$ $\mathrm{mm})$ and small fractions $(>250 \mu \mathrm{m})$ by washing the contents of a sample through nested sieves. We quantitatively subsampled each size fraction using a sample splitter and identified invertebrates to the lowest practical taxonomic unit and enumerated and measured them to the nearest $1 \mathrm{~mm}$ with an ocular micrometer under a dissecting microscope at 10 to $15 \mathrm{X}$. We converted length to biomass using length weight regressions developed for the Colorado River, or in some cases we used published values (Benke and others, 1999; Cross and others, in press). 
Table 1. Type and number of samples taken in each habitat type at the three sampling locations.

\begin{tabular}{|c|c|c|c|}
\hline Site & Depositional & Talus/Cliff & Cobble/Gravel \\
\hline & Ponar & Suction & Hess/rock grab \\
\hline RM 0 & 10 & 6 & 4 (Hess) \\
\hline RM 62 & 10 & 4 & 6 (rock grab) \\
\hline RM 225 & 10 & 7 & 3 (rock grab) \\
\hline
\end{tabular}

We tested for the short-term effects of the HFE on macroinvertebrates by examining whether biomass of individual patches was reduced following the HFE. Because these data were not normally distributed, we used a bootstrapping technique to analyze these data. For each post-HFE sampling date, we calculated the change in biomass of each sampling site (post-HFE biomass verses pre-HFE biomass), yielding 20 patch-level estimates of biomass change for each site and time interval. These 20 biomass change values were randomly sampled with replacement 20 times to calculate a bootstrapped mean biomass reduction among patches. This resampling was repeated 10,000 times to yield a bootstrapped distribution. Mean was the 50th percentile (that is, median of this distribution) and associated 90-percent confidence intervals corresponded to the 5- and 95-percent quantiles of the bootstrapped distribution. If the 95-percent quantile was less than 0 , we interpreted this finding as a significant reduction in biomass.

For the RM 0 site, we sampled benthic invertebrates monthly in the same manner as described above from July 2006 through June 2009. We estimated annual rates of macroinvertebrate secondary production for 3 years using multiple cohort and noncohort-based techniques (Benke, 1993; Benke and Huryn, 2006). Year-1 estimates were calculated using biomass data from July 2006 to June 2007, year-2 estimates were calculated using July 2007 to June 2008 data, and year-3 estimates were calculated using July 2008 to June 2009 data. Because production calculations were made from July to June, year 1 was entirely before the HFE; the HFE occurred in March of year 2, so that year included 4 post-HFE months; and year 3 was entirely after the HFE. Detailed methods are described in Cross and others (in press). All data were resampled with a bootstrapping technique to generate 95-percent confidence intervals for annual production estimates (Morin and others, 1987; Benke and Huryn, 2006). Sizespecific abundance data from replicate samples on each date were resampled with replacement 1,000 times to generate estimates of mean size-specific abundance and biomass. Biomass estimates were multiplied by size-specific growth rates and the time interval between sampling dates to generate 1,000 estimates of interval production, which were summed across intervals to calculate annual production. Annual production was estimated on a per square meter basis for each habitat and weighted according to the relative proportions of each habitat per square meter of river (see Cross and others, in press, for details on habitat weighting). If bootstrapped 95-percent confidence intervals did not overlap, production differences among years were considered significant. To augment this study, similar data on invertebrate biomass and production are in the process of being generated for several other sites in Grand Canyon (including RM 62 and RM 225) over the same 3-year time period (see Discussion below). 


\section{Invertebrate Drift and Export}

We estimated rates of invertebrate drift and total export of invertebrates from the RM 0 site before, during, and after the HFE following the methods of McKinney and others (1999). We used a plankton net with a 50-cm opening, $0.25-\mu \mathrm{m}$ mesh, and 8:1 ratio of net length to opening diameter (to minimize back pressure and clogging) that was outfitted with a flowmeter (General Oceanics Inc., Miami, Fla.) in the mouth to collect drift samples. Samples were collected from a boat that maintained position in the thalweg. Samples were depth integrated by slowly raising and lowering the weighted net (45-kg sounding weight). The sounding weight was attached to the bottom of a 1-m-long chain and the chain was attached to the winch cable - the net was clipped to the middle of the chain to ensure it did not collect benthic material. The net was deployed for 100 to 300 seconds, depending on flow conditions. Before each sampling event, the winch and sounding weight were used to take a depth measurement, and during sampling the sounding weight was not lowered past $0.5 \mathrm{~m}$ above the bed to ensure bed material was not suspended and collected in the net. Samples were collected at five evenly spaced intervals during daylight hours between 07:00 and 19:00 hours local time. Triplicate samples were collected during each sampling event for a total of 15 samples per day of sampling. All 15 samples collected before and after the HFE were processed for invertebrates. For samples collected during the HFE, one replicate from each of the five sampling events per day was randomly selected for invertebrate processing; other samples were processed for organic matter content (processing of these samples is ongoing). We preserved samples in the field and processed them as above for benthic invertebrate collections. The volume of water filtered, which was used to determine concentrations of organisms in drift, was typically between 10 to $80 \mathrm{~m}^{3}$. Daily export rates before, during, and after the HFE were estimated by multiplying average daily concentrations (number $/ \mathrm{m}^{3}$ or $\mu \mathrm{g} / \mathrm{m}^{3}$ ) by the instantaneous discharge record for that day (U.S. Geological Survey Gage 09380000). Statistical analysis of these data is ongoing - in this report we present summary statistics for concentrations and daily export rates. We also evaluated whether the HFE affected the composition of invertebrates in the drift by estimating the ratio of common digestible taxa found (Gammarus lacustris, Tubificidae, Chironomidae, Simuliidae) to a common indigestible taxa (P. antipodarum).

\section{Macroinvertebrate Diet Analysis}

At the RM 0 site, we sampled select benthic invertebrates quarterly to measure the composition of diets using gut-content analysis (Benke and Wallace, 1980; Rosi-Marshall and Wallace, 2002; Hall and others, 2000) during the 3-year period encompassing the HFE. These data were collected as part of the parallel study to construct food webs at this and other sites in Grand Canyon (see Discussion). We haphazardly collected invertebrates on the same dates that we collected quantitative benthic samples and preserved them in the field in Kahle's solution (Stehr, 1987). We examined diets of the four dominant macroinvertebrate taxa [Potamopyrgus antipodarum (New Zealand mud snails; Gastropoda: Neotaenioglossa: Hydrobiidae), Gammarus lacustris (Crustacea: Amphipoda: Gammaridae), chironomids (Insecta: Diptera: Chironomidae), and Simulium arcticum (Insecta: Diptera: Simuliidae)]. Invertebrate gut contents were removed and sonicated to break up larger particles. Gut contents were then drawn onto 25-mm Metricel filters (pore size $0.45 \mu \mathrm{m}$, Pall Corp., Port Washington, N.Y.) and filters were mounted onto microscope slides using Type B immersion oil. We measured gut contents using a compound microscope $(100 \mathrm{X})$ attached to a computer with image analysis software (ImagePro Plus, Media Cybernetics Inc., Bethesda, Md.). We identified particles in the guts into categories (for example, diatoms or amorphous detritus) and made areal estimates and converted contents into the percent composition of diets. In particular, we were interested in whether the HFE corresponded to a 
shift in the use of diatoms, a high-quality food resource. Statistical analysis of these data is not complete; here we present means and standard errors of the proportion of diatoms, which is adequate to examine patterns associated with the HFE.

\section{Results}

\section{Benthic Macroinvertebrates}

\section{Short-Term Response of Macroinvertebrates to the 2008 HFE}

Total biomass and the relative biomass of individual taxa differed among the three sites examined before the 2008 HFE (fig. 3). The composition of the benthic assemblage at RM 0 was dominated by the following taxa: P. antipodarum (New Zealand mud snails), G. lacustris, Tubificidae, Lumbricidae, and Chironomidae. In cobble habitats, $P$. antipodarum, Tubificidae, and Lumbricidae dominated the assemblage and total biomass was on average $4 \mathrm{~g}$ AFDM $/ \mathrm{m}^{2}$ (expressed as grams ashfree dry mass, or AFDM). P. antipodarum and Tubificidae also dominated depositional habitats, but these areas had lower average biomass $\left(2.5 \mathrm{~g}\right.$ AFDM $\left./ \mathrm{m}^{2}\right)$. Talus slopes and cliff faces (fig. 3, Talus) were dominated by G. lacustris and had generally the lowest biomass of all habitats at RM 0. Simulium arcticum (blackflies) and Chironomidae were present at RM 0 but at relatively low abundance and biomass.

The macroinvertebrate assemblage of downstream sites had lower biomass (ranging from 0.14 to $0.4 \mathrm{~g} \mathrm{AFDM} / \mathrm{m}^{2}$ ) compared to RM 0 (ranging from 2 to $4 \mathrm{~g} \mathrm{AFDM} / \mathrm{m}^{2}$ ) and was dominated by different taxa (fig. $3 B$ and $C$ ). The macroinvertebrate assemblage at RM 62 was generally dominated by $S$. arcticum, Tubificidae, and Chironomidae in cobble habitats and some Tubificidae, G. lacustris, and Chironomidae in the talus and cliff-face habitats. Biomass of the invertebrate assemblage at RM 62 was less than one tenth the biomass at RM 0. At RM 225, the macroinvertebrate assemblage in cobble habitats was dominated by S. arcticum and Chironomidae. In talus and cliff-face habitats, S. arcticum, Tubificidae, and Chironomidae were present, and P. antipodarum and G. lacustris were also present in these habitats in higher biomass than we observed at RM 62. These pre-HFE differences among sites in terms of relative composition and total biomass provided the baseline against which we assessed the effects of the $2008 \mathrm{HFE}$ on the macroinvertebrate assemblage.

The HFE immediately reduced total invertebrate biomass at RM 0 but not at downstream sites (fig. 4). At RM 0 the HFE significantly lowered invertebrate biomass by an average of $1.75 \mathrm{~g}$ AFDM $/ \mathrm{m}^{2}$ across all patches, and the biomass of patches continued to decline on subsequent days. In contrast, at RM 62 and RM 225 there were no significant reductions in total benthic macroinvertebrate biomass immediately following the HFE, but on the last dates sampled ( 25 to 40 days after the HFE), confidence intervals did not overlap 0 , indicating that by this point there had been a significant decline in biomass relative to pre-HFE values. 

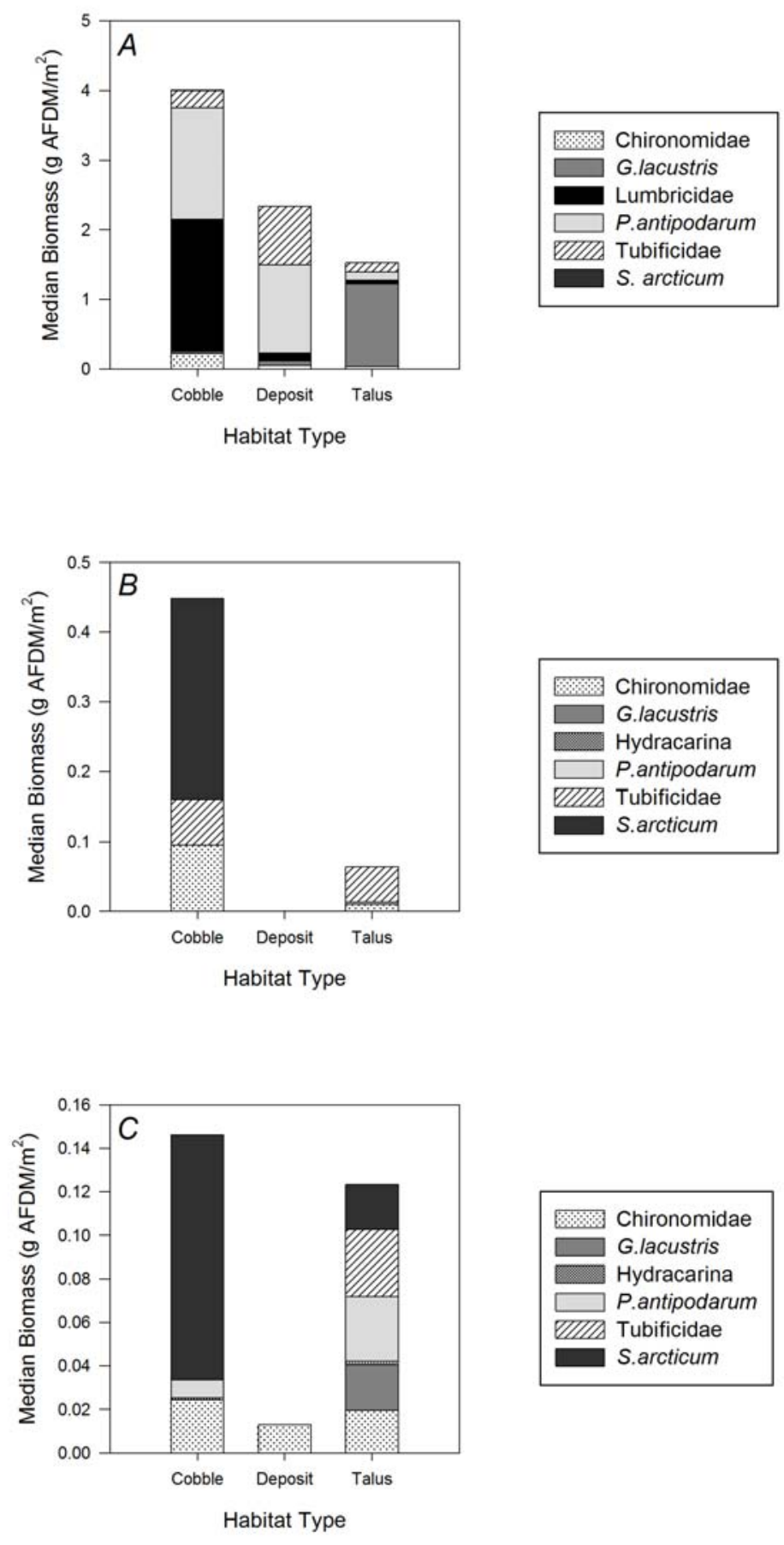

Figure 3. Bar graphs showing macroinvertebrate biomass measured in $\mathrm{g} \mathrm{AFDM} / \mathrm{m}^{2}$ (ash-free dry mass, or AFDM) and relative taxa composition in the three dominant habitat types (cobble, depositional (deposit), and talus) at the three study sites on the Colorado River in Arizona: $(A)$ river mile (RM) 0, $(B)$ RM 62, and $(C)$ RM 225 in March 2008, 1 day before the high-flow experiment. River mile is used to describe distance along the Colorado River in Grand Canyon: Lees Ferry is the starting point, as RM 0, with mileage measured for both upstream (-) and downstream directions. 

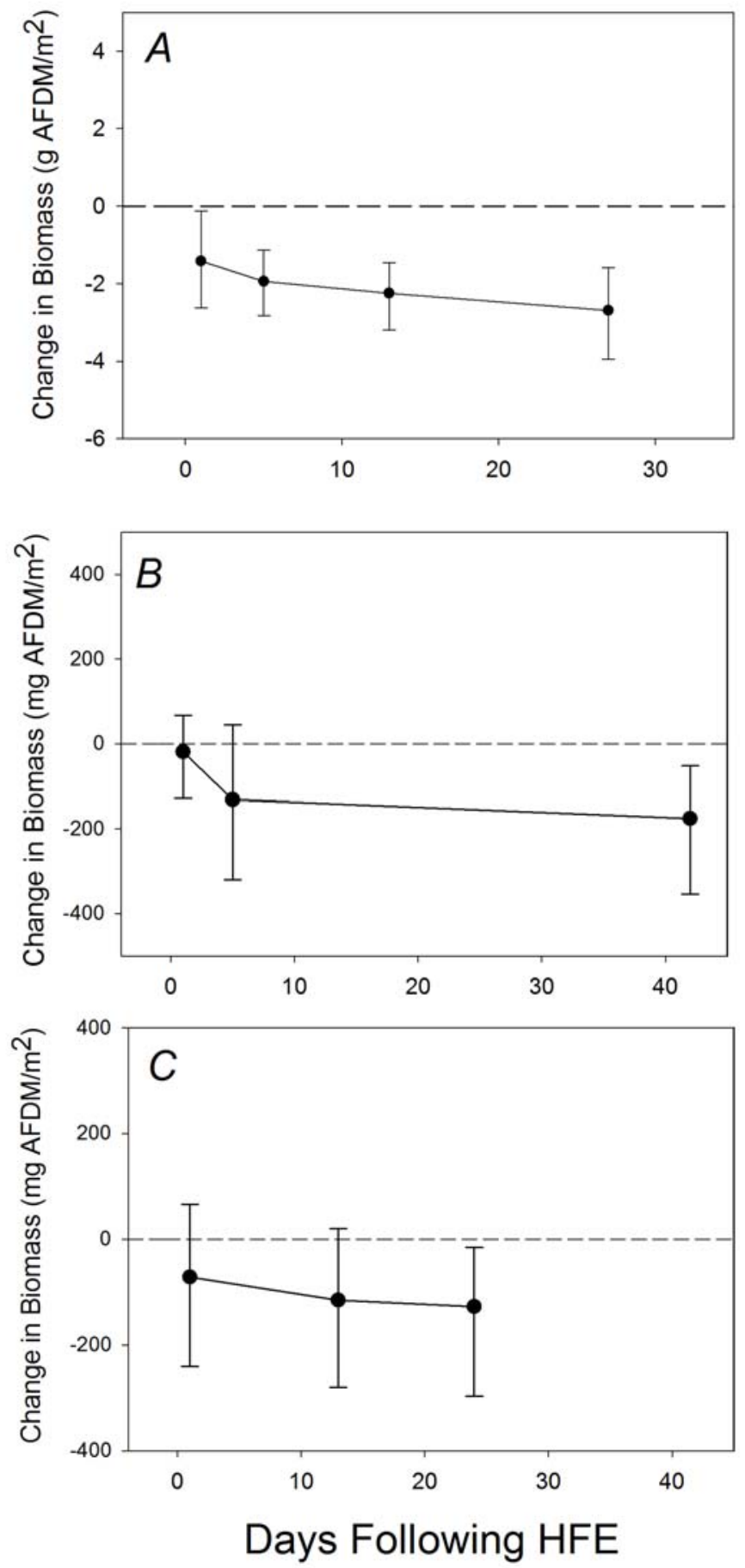

Figure 4. Line graphs showing the change in total benthic macroinvertebrate biomass measured in $\mathrm{g}$ or $\mathrm{mg}$ AFDM $/ \mathrm{m}^{2}$ (ash-free dry mass, or AFDM) at river mile (RM) $0(A)$, RM $62(B)$, and RM $225(C)$ following the March 2008 high-flow experiment. Error bars illustrate the 95-percent confidence intervals of the mean. Note the scale of the $y$-axis changes from grams (g) at RM 0 to milligrams (mg) at RM 62 and RM 225. River mile is used to describe distance along the Colorado River in Grand Canyon: Lees Ferry is the starting point, as RM 0 , with mileage measured for both upstream (-) and downstream directions. 
The effects of the HFE on biomass of individual taxa varied by site and time after the HFE. At RM 0, biomass of four taxa immediately declined following the HFE relative to pre-HFE conditions (fig. 5). P. antipodarum, in particular, significantly declined in biomass on the first day after the HFE, and their biomass continued to decline relative to their pre-HFE biomass (fig. 5A). G. lacustris, Lumbricidae, and Tubificidae also declined following the HFE (fig. 5C, D, and $E$, respectively). Similar to $P$. antipodarum, Lumbricidae and Tubificidae continually decreased over time after the HFE. In contrast, G. lacustris had lower biomass 1 day after the HFE and after this change in biomass relative to the pre-HFE condition remained relatively constant throughout the sampling period. Chironomid and blackfly biomass were not significantly lower following HFE relative to the pre-HFE condition (indicated by a change in biomass that was approximately equal to 0 ). However, recall that these taxa were relatively rare at RM 0 during March 2008 before the HFE (fig 3).

Biomass of certain taxa declined following the HFE at RM 62, but the magnitude of the reduction was lower, and the taxa affected differed, relative to RM 0. P. antipodarum, an extremely rare taxon at RM 62, was not significantly affected by the HFE at this site (fig. 6A). Similar to RM 0, G. lacustris biomass was significantly reduced at RM 62 (fig. 6B). However, this taxon was also relatively rare at RM 62. In fact, the much lower biomass of invertebrates at this site in general (note 10-fold difference in units on the y-axis between figs. 5 and 6) meant that although the reduction in G. lacustris was statistically significant, the total change in their biomass was far less than what occurred at RM 0. Biomass of chironomids, which were more dominant at this site, as well as tubificids, was significantly reduced 5 and 42 days after the HFE (figs. 6C and 6D). Simuliidae were the dominant taxa at RM 62 (fig. 3), and they were not significantly affected on 1 or 5 days after the HFE (fig. $6 E$ ); however, by day 42 , there was significantly lower simuliid biomass than pre-HFE. 


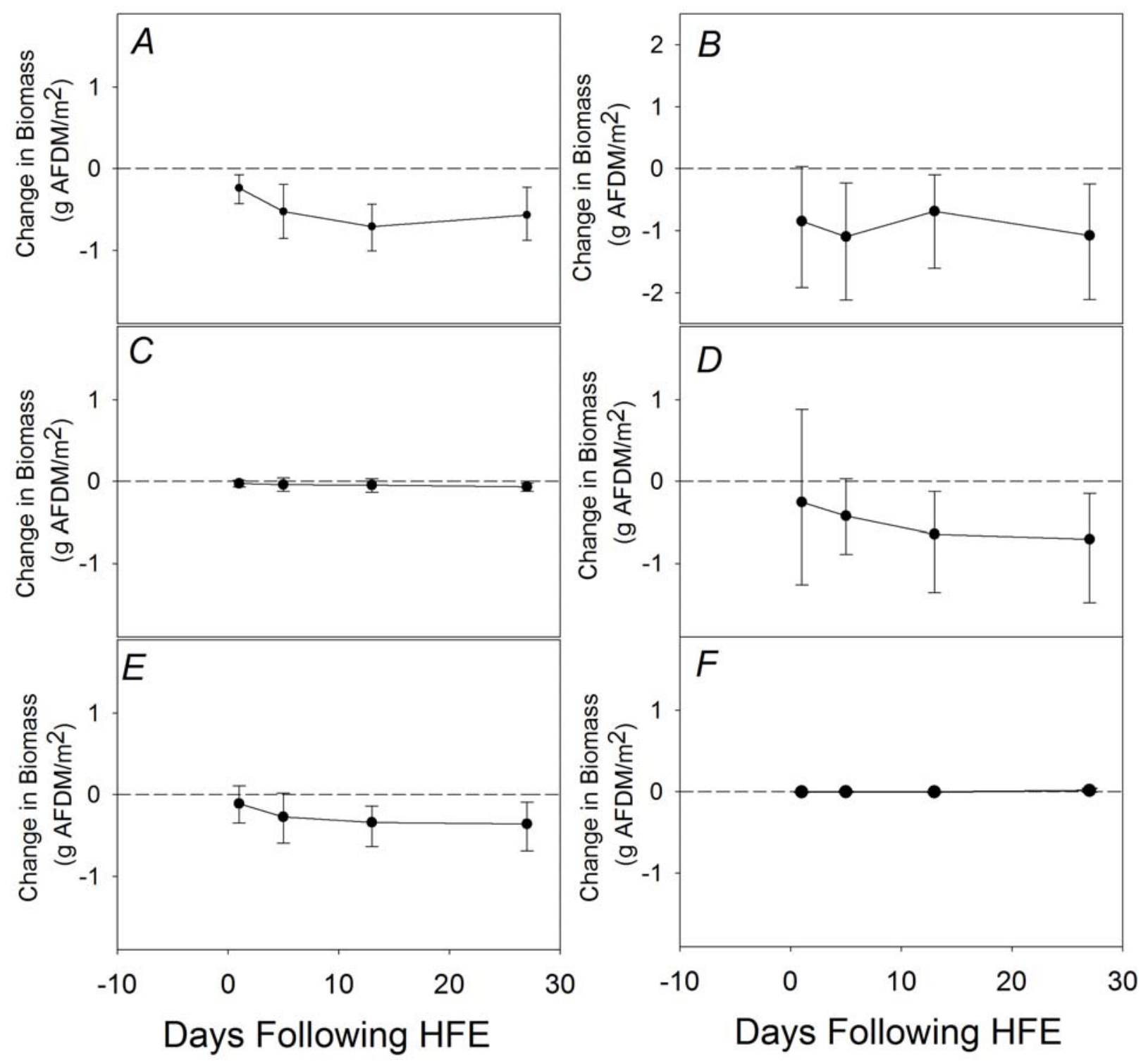

Figure 5. Line graphs showing changes in biomass in benthic macroinvertebrate taxa measured in $\mathrm{AFDM} / \mathrm{m}^{2}$ (ash-free dry mass, or AFDM) at river mile (RM) 0 following the March 2008 high-flow experiment (HFE): (A) Potamopyrgus antipodarum, (B) Gammarus lacustris, $(C)$ Chironomidae, (D) Lumbricidae, (E) Tubificidae, and (F) Simuliidae. Error bars illustrate the 95-percent bootstrap confidence intervals of the mean. River mile is used to describe distance along the Colorado River in Grand Canyon: Lees Ferry is the starting point, as RM 0 , with mileage measured for both upstream (-) and downstream directions. 


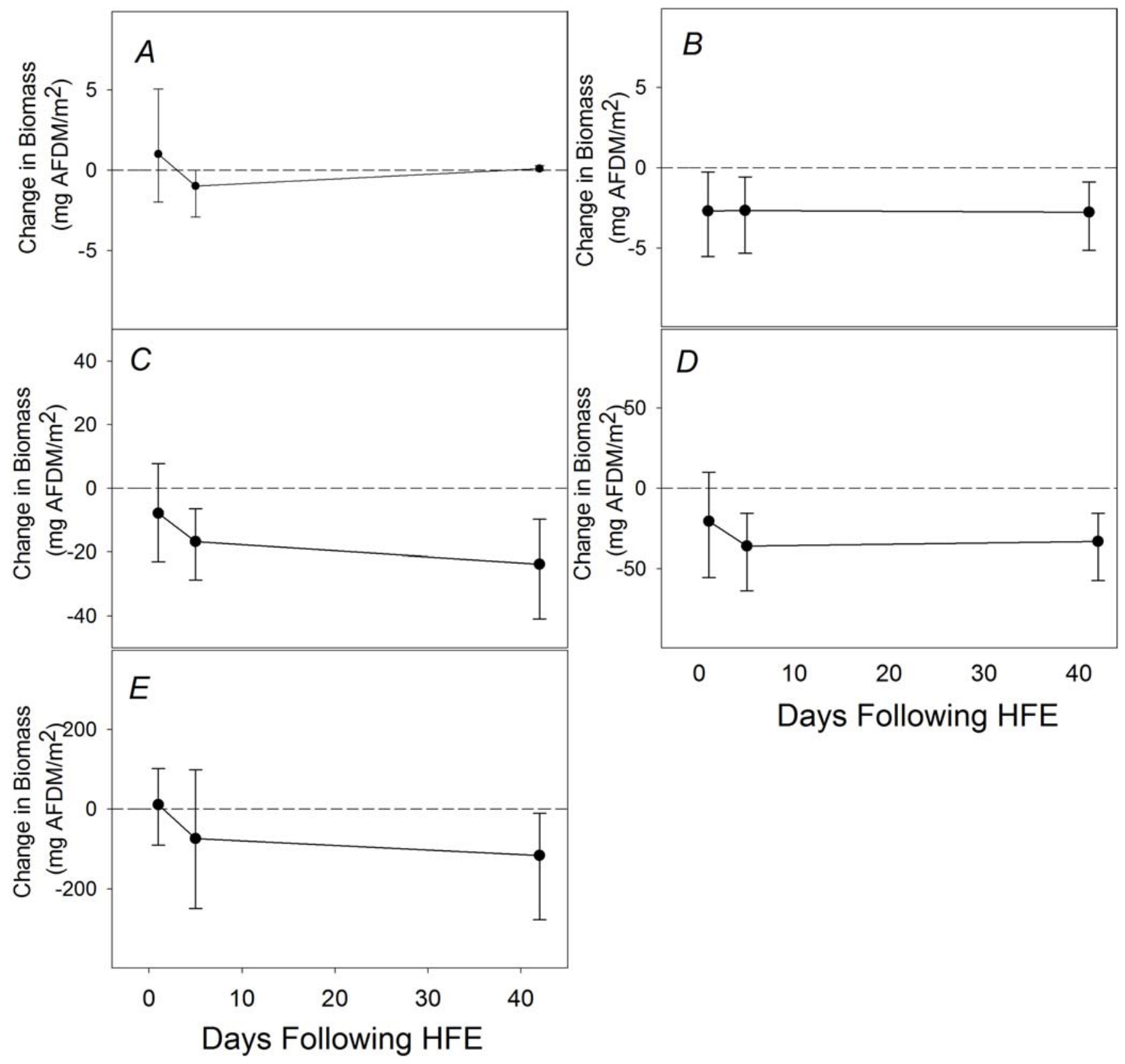

Figure 6. Changes in biomass measured in $\mathrm{mg} \mathrm{AFDM} / \mathrm{m}^{2}$ (ash-free dry mass, AFDM) at river mile (RM) 62 following the March 2008 high-flow experiment (HFE), (A) Potamopyrgus antipodarum, (B) Gammarus lacustris, $(C)$ Chironomidae, $(D)$ Tubificidae, and $(E)$ Simuliidae. Error bars illustrate the 95-percent bootstrap confidence intervals of the mean. River mile is used to describe distance along the Colorado River in Grand Canyon: Lees Ferry is the starting point, as RM 0 , with mileage measured for both upstream (-) and downstream directions. 
The impact of the HFE on individual taxa at RM 225 was similar to that observed at RM 62 (fig. 7). $P$. antipodarum, which was more common at RM 225 than at RM 62, was not significantly reduced by the HFE (fig. 7A). Similar to the other sites, biomass of G. lacustris and chironomids was significantly lower relative to their pre-HFE biomass (figs. $7 B$ and $7 C$, respectively). Tubificids biomass was significantly lower on day 24 relative to their pre-HFE condition at this site (fig. $7 D$ ). The dominant taxon at RM 225 was Simuliidae (fig. 3), and it was not initially affected by the HFE (fig. 7E).

However, as we observed for simuliids at RM 62, by the last sampling date (day 42), their biomass was significantly lower than before the HFE.

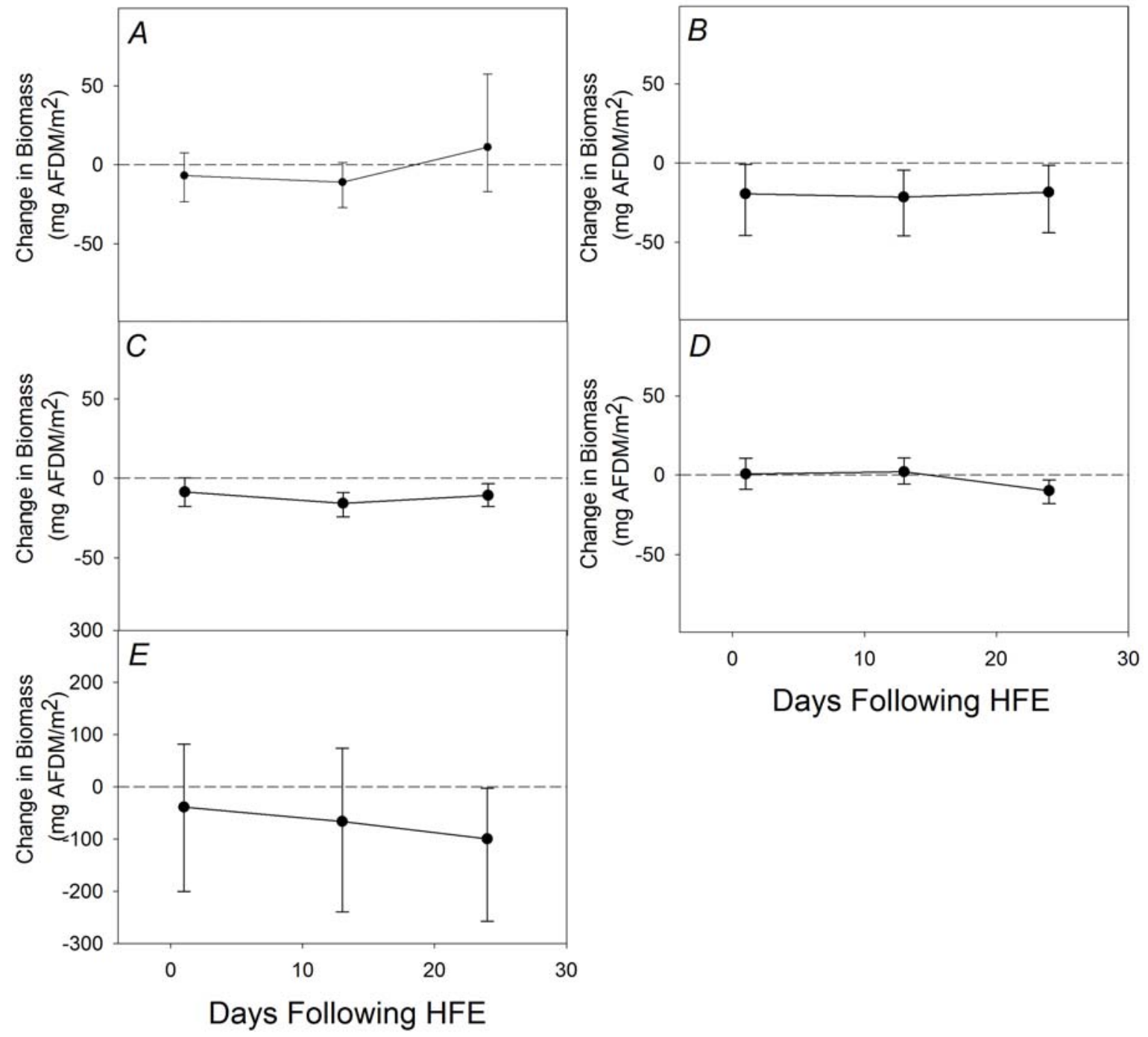

Figure 7. Line graphs showing change in biomass measured in $\mathrm{mg}$ AFDM $/ \mathrm{m}^{2}$ (ash-free dry mass, AFDM) of individual taxa at river mile (RM) 225 after the March 2008 high-flow experiment (HFE): (A) Potamopyrgus antipodarum, $(B)$ Gammarus lacustris, $(C)$ Chironomidae, $(D)$ Tubificidae, and $(E)$ Simuliidae. Error bars illustrate the 95-percent bootstrap confidence intervals of the mean. River mile is used to describe distance along the Colorado River in Grand Canyon: Lees Ferry is the starting point, as RM 0, with mileage measured for both upstream (-) and downstream directions. 


\section{Invertebrate Drift and Export}

The 2008 HFE exported substantial numbers and biomass of invertebrate taxa from the RM 0 reach. Concentrations of dominant invertebrate taxa in the drift increased substantially on the first day of the HFE relative to pre-HFE concentrations (fig. 8). Export of $P$. antipodarum and Tubificidae were highest on the second day of the HFE and then decreased on subsequent days (figs. $8 \mathrm{~A}$ and $8 E$, respectively). In contrast, export of $G$. lacustris peaked on the first day of the HFE and decreased on subsequent days of the HFE (fig. 8B). Chironomids, lumbricids, and simuliids export did not increase in the drift during the course of the HFE. Another way to examine this shift in the composition of the drift at RM 0 is by computing the ratio of taxa digestible to rainbow trout (Gammarus lacustris, Tubificidae, Chironomidae, and Simuliidae) to the indigestible P. antipodarum in drift samples (fig. 9). Before the $2008 \mathrm{HFE}$ this ratio was occasionally less than 1 (there were more P. antipodarum than digestible taxa in the drift), but after the HFE this ratio was much greater than 1. 

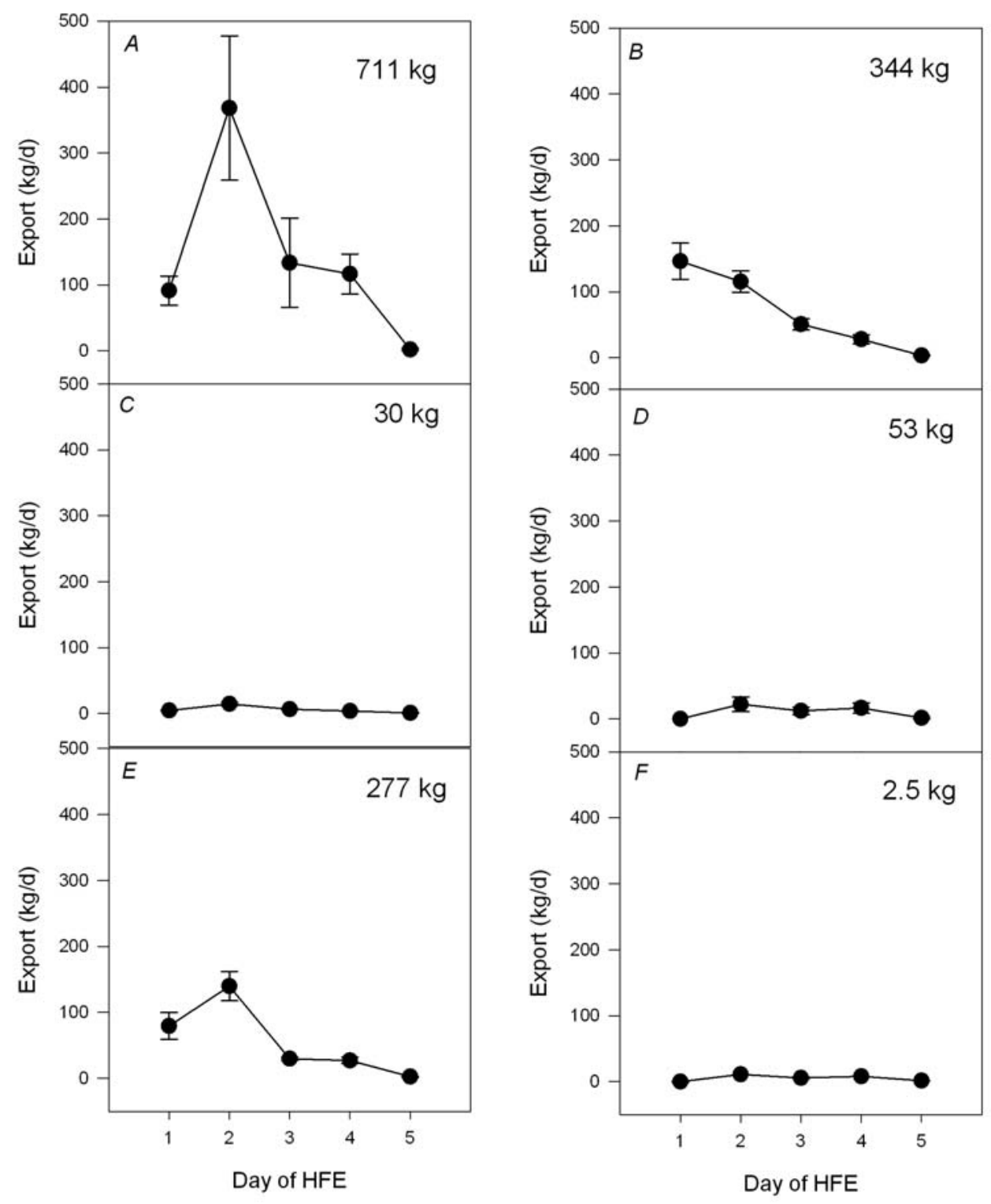

Figure 8. Export of benthic invertebrates in drift $(\mathrm{kg} / \mathrm{d})$ from river mile 0 on the Colorado River during the March 2008 high-flow experiment (HFE): (A) Potamopyrgus antipodarum, (B) Gammarus lacustris, (C) Chironomidae, $(D)$ Lumbricidae, $(E)$ Tubificidae, and $(F)$ Simuliidae. The total estimated export (in $\mathrm{kg}$ ) during the 5-day-long HFE appears within each panel. River mile is used to describe distance along the Colorado River in Grand Canyon: Lees Ferry is the starting point, as river mile 0 , with mileage measured for both upstream (-) and downstream directions. 

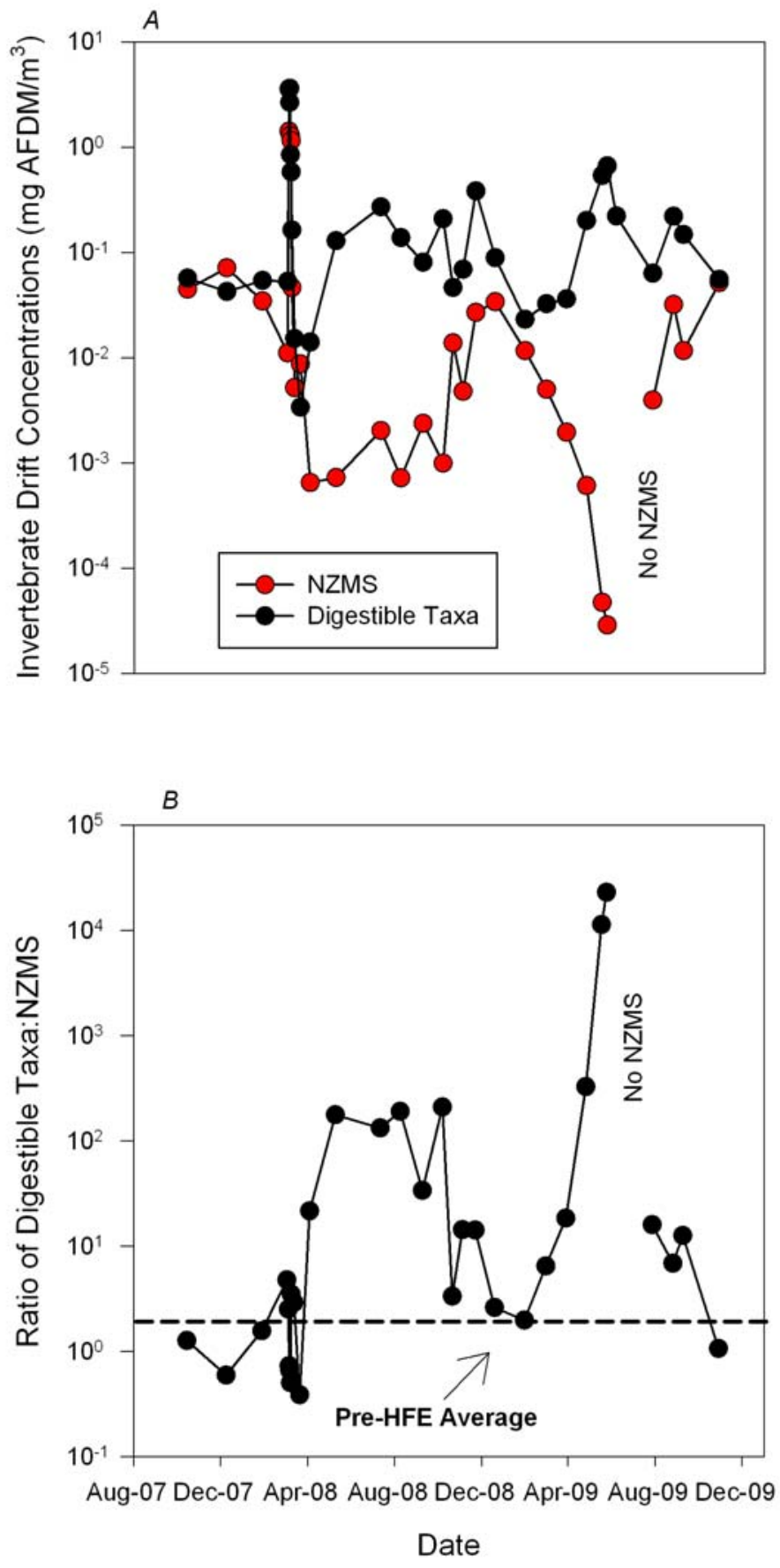

Figure 9. Concentrations of invertebrate taxa in the drift at river mile (RM) 0 along the Colorado River from August 2007 to December 2009. (A) Taxa found in the drift measured in $\mathrm{mg}$ AFDM $/ \mathrm{m}^{2}$ (ash-free dry mass, AFDM) that can be digested by rainbow trout (including Gammarus lacustris, Tubificidae, Chironomidae, Simuliidae) and the indigestible New Zealand mud snail (NZMS) (Potamopyrgus antipodarum), and (B) the ratio of digestible taxa to mud snails in the drift. River mile is used to describe distance along the Colorado River in Grand Canyon: Lees Ferry is the starting point, as river mile 0 , with mileage measured for both upstream (-) and downstream directions. 


\section{Long-Term Macroinvertebrate Assemblage Dynamics}

Using longer term data presently available for RM 0, we were able to detect that the short-term effects of the HFE on two taxa-P. antipodarum and $G$. lacustris - translated into significant reductions in their average annual biomass and production. Biomass of $G$. lacustris and P. antipodarum at RM 0 was considerably lower in year 3 relative to years 1 and 2 (fig. 10A), and this finding was associated with significantly lower production for these same taxa in year 3 as well; $P$. antipodarum production declined from 11 to $13 \mathrm{~g} \mathrm{AFDM} / \mathrm{m}^{2} / \mathrm{yr}$ in years 1 and 2 to only $2 \mathrm{gAFDM} / \mathrm{m}^{2} / \mathrm{yr}$ in year 3 (fig. $10 B$, table 2; nonoverlapping 95-percent CIs). G. lacustris production was also lower in year 3, but the relative decrease was less than for P. antipodarum; in years 1 and 2, G. lacustris production ranged from 7 to $8 \mathrm{~g} \mathrm{AFDM} / \mathrm{m}^{2} / \mathrm{y}$ and declined to $3 \mathrm{~g} \mathrm{AFDM} / \mathrm{m}^{2} / \mathrm{yr}$ in year 3 (fig. 10B, table 2). In addition, there were also differences among years for other taxa (table 2). For example, even though the HFE reduced lumbricid biomass at RM 0 in the short term, production of Lumbricidae was actually highest in year 2, which included 4 months after the 2008 HFE. Some taxa, Chironomidae and Acari (mites), had the highest rates of secondary production in year 3. Finally, Simuliidae rates of production were significantly different among all years (table 2), with highest production in year 3 (fig. 10B).

Table 2. Invertebrate secondary production in milligrams of ash-free dry mass per meter squared per year (95percent confidence intervals) in the Glen Canyon section of the Colorado River (river mile 0), Ariz., between July 2006 and June 2009.

[Lower case letters indicate significant differences in production for a given taxa among years (nonoverlapping confidence intervals). River mile is used to describe distance along the Colorado River in Grand Canyon: Lees Ferry is the starting point, as river mile 0 , with mileage measured for both upstream (-) and downstream directions]

\begin{tabular}{|c|c|c|c|}
\hline Taxon & $\begin{array}{c}\text { Year } 1 \\
\text { (July 06-June 07) }\end{array}$ & $\begin{array}{c}\text { Year } 2 \\
\text { (July 07-June 08) }\end{array}$ & $\begin{array}{c}\text { Year } 3 \\
\text { (July 08-June 09) }\end{array}$ \\
\hline P. antipodarum & $13,300(10,200-16,700)^{\mathrm{a}}$ & $10,700(6,800-17,000)^{\mathrm{a}}$ & $2,000(1,640-2,390)^{b}$ \\
\hline Gammarus lacustris & $7,010(5400-9,000)^{\mathrm{a}}$ & $8,690(6,540-11,000)^{\mathrm{a}}$ & $2,650(2,100-3,350)^{\mathrm{b}}$ \\
\hline Tubificidae (a) & $4,290(3,540-5,070)^{\mathrm{a}}$ & $2,860(2,320-3,480)^{\mathrm{b}}$ & $3,930(3,310-4,670)^{\mathrm{ab}}$ \\
\hline Turbellaria & $754(577-983)^{\mathrm{a}}$ & $382(287-489)^{\mathrm{b}}$ & $577(428-748)^{\mathrm{ab}}$ \\
\hline Physidae & $1,080(676-1,630)^{\mathrm{a}}$ & $494(373-627)^{\mathrm{b}}$ & $500(388-626)^{\mathrm{b}}$ \\
\hline Lumbricidae & $706(526-905)^{\mathrm{a}}$ & $5,470(2,540-9,400)^{\mathrm{b}}$ & $634(428-859)^{\mathrm{a}}$ \\
\hline Chironomidae & $559(433-690)^{\mathrm{a}}$ & $657(548-757)^{\mathrm{a}}$ & $937(808-1,070)^{\mathrm{b}}$ \\
\hline Ostracoda & $274(183-377)^{\mathrm{a}}$ & $70.4(53.0-90.2)^{\mathrm{b}}$ & $31.0(26.0-35.9)^{\mathrm{c}}$ \\
\hline Nematoda & $116(95-142)^{\mathrm{a}}$ & $127(92-167)^{\mathrm{a}}$ & $215(184-249)^{\mathrm{b}}$ \\
\hline Sphaeridae & $116(41.4-219)^{\mathrm{a}}$ & $28.7(2.20-58.2)^{\mathrm{a}}$ & $62.0(43.0-84.8)^{\mathrm{a}}$ \\
\hline Simuliidae & $49.3(21.1-83.5)^{\mathrm{a}}$ & $348(141-604)^{\mathrm{b}}$ & $1,180(672-1,820)^{\mathrm{c}}$ \\
\hline Cladocera & $37.2(25.6-49.8)$ & $45.9(17.0-85.4)$ & $53.0(35.6-72.8)$ \\
\hline Copepoda & $35.7(26.0-46.5)$ & $29.0(19.3-40.1)$ & $37.0(28.6-45.6)$ \\
\hline Tubificidae (b) & $57.0(27.7-109)$ & $27.2(12.5-46.0)$ & $86.0(53.0-124)$ \\
\hline Ceratopogonidae & $\begin{array}{l}.000779(.0000267- \\
0.00219)\end{array}$ & $0.000130(0-0.000328)$ & 0 \\
\hline Acari & $\begin{array}{l}0.000917(0.000273- \\
0.00189)\end{array}$ & $\begin{array}{l}0.0000448(0.0000962- \\
0.00000469)\end{array}$ & 0 \\
\hline
\end{tabular}


A

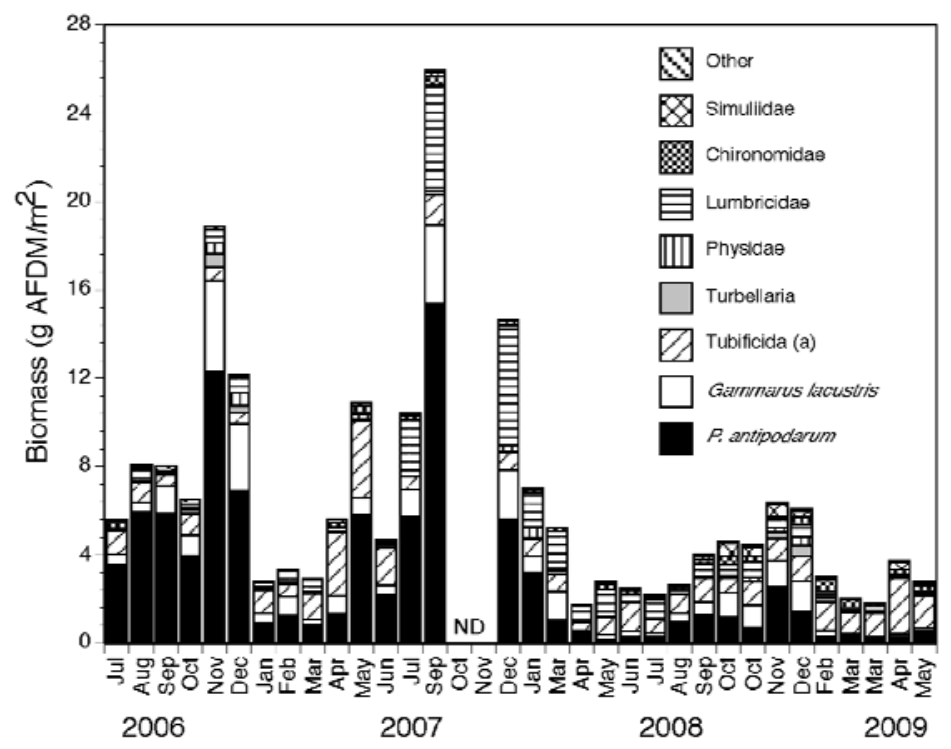

B

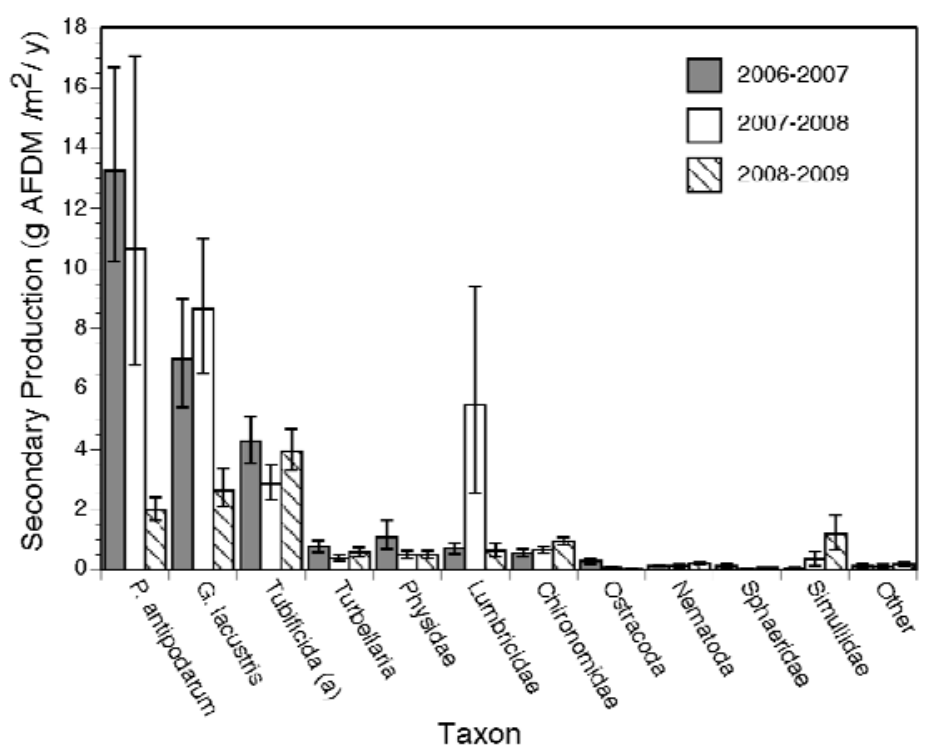

Figure 10. Bar graphs showing long-term macroinvertebrate assemblage dynamics at river mile 0 on the Colorado River. (A) Biomass over time for the six most common taxa with the timing of the high-flow experiment, which occurred from March 5-9, 2008. (B) Secondary production of all taxa in year 1 (July 2006-June 2007), year 2 (July 2007-June 2008), and year 3 (July 2008-June 2009). Error bars are \pm 95 -percent bootstrap confidence intervals. River mile is used to describe distance along the Colorado River in Grand Canyon: Lees Ferry is the starting point, as river mile 0 , with mileage measured for both upstream (-) and downstream directions. 


\section{Macroinvertebrate Diets}

The feeding habits of select macroinvertebrate taxa at RM 0 were not changed by the $2008 \mathrm{HFE}$ (fig. 11). Invertebrates consumed a high proportion of diatoms in this reach, and that pattern did not change in response to the HFE (fig. 11). The remaining proportion of the diet composition (fig. 11) is typically composed of amorphous detritus.
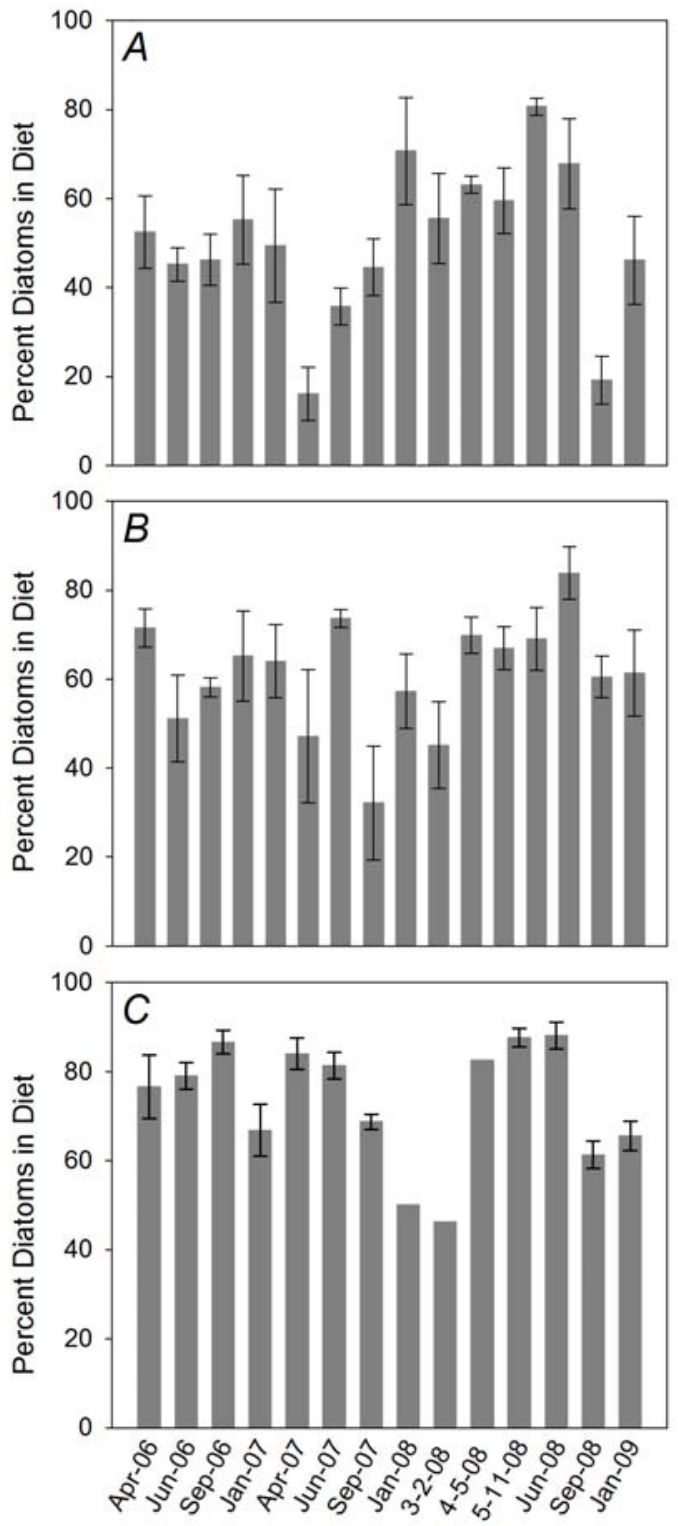

Figure 11. Bar graphs showing the percentage of diatoms in macroinvertebrate diets for $(A)$ Gammarus lacustris, (B) Potamopyrgus antipodarum, and (C) Simuliidae before and after the March 2008 high-flow experiment. Error bars are \pm one standard error. 


\section{Discussion and Implications for Management}

Our study was aimed at quantifying short-term effects of the 2008 HFE on macroinvertebrate communities at three sites in the Colorado River. We monitored changes at a short temporal scale to examine acute effects of the HFE on key invertebrate taxa at sites of high management importance. We also aimed to capture a broad spatial snapshot of short-term effects throughout the Colorado River. Our results, coupled with ongoing long-term food base research, should provide an integrated view of shortterm and longer term effects of HFEs on macroinvertebrate consumers. We focus on macroinvertebrates because they are sentinels of change in river ecosystems and support a large proportion of native and nonnative fish production. In addition, examining HFEs within the context of long-term data is essential for evaluating the long-term consequences of adaptive management decisions.

Our findings demonstrate that the effects of a HFE on invertebrates may persist at least 15 months, the amount of time considered by this study, in the clear tailwater below the dam. During the 2008 HFE, the benthos of the Colorado River were scoured, which led to increases in drifting invertebrates and initial decreases in the benthic biomass of some taxa at some sites. This pattern is consistent with observations by Shannon and others (2001) after the 1996 HFE and has been observed in the context of HFEs on other river systems as well (Robinson and others, 2004). At RM 0, the HFE was associated with an immediate reduction in total biomass of the macroinvertebrate assemblage, and our long-term dataset revealed that reductions in biomass of $P$. antipodarum and G. lacustris persisted for at least 15 months after the HFE. In addition, this coincided with a significant reduction in the annual production of these taxa. Short-term biomass reductions of other common taxa (aquatic worms in the families Lumbricidae and Tubificidae) did not persist, and these taxa recovered within approximately 4 to 6 months after the HFE. In contrast, downstream sites had no significant reductions in total assemblage biomass, but some individual taxa were lower following the HFE. We expect that these reductions will not translate into a decline in production, and future analysis of our long-term dataset will address this question.

Some taxa appeared particularly susceptible to the effects of the HFE, regardless of site. For example, G. lacustris had lower biomass at all sites, perhaps because they are relatively large and readily entrained into the drift. During the HFE, they were abundant in the drift at RM 0 and constituted a substantial portion of the biomass of the drifting invertebrates that were exported from this reach. Fifteen months after the HFE, benthic biomass at RM 0 of G. lacustris was still less than half its preHFE biomass, and annual secondary production of G. lacustris in the year following the HFE was significantly lower than in the two previous years. This is similar to the findings of Robinson and Uehlinger (2008), who also found that it took slow-growing taxa, such as gammarids, longer to recover to preflood levels of biomass relative to faster growing taxa with aerial life stages such as blackflies or chironomids. High-flow conditions will affect species differently, and the threshold of these responses is not linear (Shaforth and others, 2009). For example, in the Bill Williams River, a dryland river that is a large tributary of the Colorado River, numerous environmental flow experiments were conducted to develop quantitative relationships between flow regimes and ecological endpoints (Shaforth and others, 2009). Quantifying these nonlinear relations between flow and ecological responses will demonstrate how various flow modifications influence specific taxa in the Grand Canyon ecosystem.

The biomass and production of $G$. lacustris was apparently affected by the HFE, but its diet did not change in response to the HFE. Even 1 day after the HFE, the G. lacustris collected at RM 0 had a high proportion of diatoms in their guts. These diet data may indicate that although conditions of scour occurred and resulted in removal of organisms, the scour of algal biofilms was less dramatic. Data on primary production will ultimately address whether food resources for G. lacustris and other consumers 
were more limiting following the HFE. We are currently analyzing a long-term record of primary production at RM 0, and an analysis of potential algal resource availability is forthcoming.

The nonnative New Zealand mud snail, $P$. antipodarum, declined dramatically in biomass following the HFE. This taxon dominated the benthic assemblage in RM 0 before the HFE, and during the HFE they were the numerically dominant fraction of the drift and export from the tailwater reach below the dam. Indeed, we calculated that $711 \mathrm{~kg}$ of $P$. antipodarum were scoured during the HFE, which was twofold greater than G. lacustris $(344 \mathrm{~kg})$ export and more than 20 -fold greater than chironomid $(29 \mathrm{~kg}$ ) export. Interestingly, even in the weeks after the HFE, P. antipodarum biomass continued to decline, suggesting continued high mortality even after the HFE, although the cause of this high mortality is not known. However, similar to G. lacustris, P. antipodarum collected 1 day and 1 month after the HFE had high concentrations of diatoms in their diets, suggesting that there were labile food resources available that were consumed by mud snails after the HFE. The reduction in biomass of P. antipodarum persisted 15 months after the HFE when monitoring stopped; P. antipodarum density, biomass, and production were still well below pre-HFE values. To estimate recovery time and the length of time required for a snail to grow from hatching (about $0.5 \mathrm{~mm})$ to reproductive adult size $(3.5 \mathrm{~mm})$ (Alonso and Castro-Diez, 2008), we used size-specific growth rates of $P$. antipodarum at RM 0 (growth rate $=-0.006 *$ snail length +0.029 ) (growth methods presented in Cross and others, in press). Applying the average growth rate of $P$. antipodarum in Glen Canyon, we estimate that it takes on average approximately 250 days to reach the size when snails begin to reproduce and contribute to the population. In other words, generation time for $P$. antipodarum at RM 0 is approximately 250 days. Thus, considering the initial reduction in abundance that we observed during the HFE, relatively slow growth rates and potentially high mortality of newly hatched snails, we predict that recovery of New Zealand mud snails to pre-HFE levels will take a minimum of 2 years.

$P$. antipodarum specimens were first reported in the Grand Canyon in 1995 and since then have become the dominant invertebrate in terms of both biomass and production (Cross and others, in press). This invasion has important implications for the Colorado River because P. antipodarum are lowquality food resources for many fishes. For example, Vinson and Baker (2008) found that rainbow trout fed an exclusive and unlimited amount of $P$. antipodarum lost between 0.14 to 0.48 percent of their body weight per day, in part because 54 percent of $P$. antipodarum passed through the digestive tract alive. $P$. antipodarum may therefore be considered a trophic dead end for at least the rainbow trout that dominate the Glen Canyon tailwater reach, because they likely contribute very little to the growth of higher trophic levels. Despite the invasive capacity of this species (Loo and others, 2007; Alonso and Castro-Diez, 2008) in the relatively cold tailwater below Glen Canyon Dam, we hypothesize that the slow daily growth rates of $P$. antipodarum resulted in slow recovery rates following the HFE. Our findings indicate that $P$. antipodarum may be controlled to some extent with HFEs taking place every 2 to 3 years, and the effectiveness of this intervention may be increased with annual HFEs.

Interestingly, biomass of blackfly larvae (Simuliidae), the dominant taxon at RM 62 and RM 225, was not immediately reduced by the HFE and did not increase in the drift during the HFE. Blackfly larvae may avoid scour associated with the HFE because of their ability to colonize and subsist in high velocity habitats (Merritt and others, 2008). Simuliids, however, did decline approximately 1 month after the HFE, but this coincided with the period of their regular emergence from the benthos as aerial adults, and therefore was not likely a result of the HFE. In fact, in years before the HFE we observed similar dynamics in simuliid biomass associated with their emergence (E.J. Rosi-Marshall and others, Cary Institute for Ecosystem Studies, unpub. data, 2010). At RM 0, where the biomass of Simuliidae is low, there were no changes in their biomass following the HFE, and in the year following the HFE the biomass and production of Simuliidae increased, possibly because of a steady flow experiment 
conducted during September and October 2008. Such observations suggest that the effects of the HFE are site specific and that differences in assemblage composition influences magnitude and direction of response to HFEs.

Changes in macroinvertebrate biomass following a HFE have implications for both native and nonnative fishes in Grand Canyon. However, understanding whether changes in macroinvertebrate biomass or production will influence growth and production of fishes will require detailed diet analysis of fish throughout the year, coupled with quantitative estimates of both invertebrate and fish production. These data can be used to assess which food resources contribute most to fish production and to test the degree to which fishes are food limited (for example, Benke and Wallace, 1980; Huryn, 1996). Our current long-term research efforts will accomplish this task at six sites in the Colorado River, including locations of the three major aggregations of humpback chub; these results are forthcoming.

Initial results from our parallel studies in Glen Canyon suggest that during years of low invertebrate production, rainbow trout consume a high proportion of low-quality food items, including algae and New Zealand mud snails (C.V. Baxter, Idaho State University, unpub. data, 2010). Interestingly, following the HFE, the relative balance of digestible versus $P$. antipodarum in the drift appeared to shift towards more digestible taxa. The pattern continued 1.5 years after the HFE, although at times it approached the pre-HFE condition. In essence, the HFE potentially reduced food quantity but increased food quality in both the benthos and drift, and this effect persisted long after the HFE. Data on growth and survival of young-of-year trout indicate that the HFE had a positive effect on these early life stages (Korman, 2010), an effect that is possibly linked to the changes in macroinvertebrates that we document. Korman (2010) also report that growth and survival rates of young trout are density dependent - both rates are lower when abundance is high. Summer and fall growth rates for rainbow trout in $2008(0.44 \mathrm{~mm} / \mathrm{d})$ were comparable to $2006(0.46 \mathrm{~mm} / \mathrm{d}$ - the highest record during the study), despite the fact that abundance in 2008 was eight times higher than in 2006 (Korman, 2010). The two most likely mechanisms for this finding are that (1) the HFE improved the habitats that are used by these young fish or (2) the HFE increased the availability of food resources eaten by these young fish. Analysis of trout diets from RM 0 and incorporation of all data into quantitative food webs is ongoing and will address this question.

The results of our study provide little support for a strong negative effect of the $2008 \mathrm{HFE}$ on benthic macroinvertebrates at downstream sites in Grand Canyon. Downstream invertebrates are consumed by native fishes (Carothers and Brown, 1991; Stevens and others, 1997; Childs and others 1998), including the endangered humpback chub. Further research examining whether the changes in mainstem invertebrate communities affect native fishes is needed. Additional changes to macroinvertebrate communities in nonmainstem habitats potentially occurred as a result of the HFE; however, these effects will be presented in a separate study focused on backwaters. We speculate that the HFE facilitated shifts in the quality of prey available to native fishes, but evaluation of this question will depend on analysis of longer term datasets, including estimates of annual production and food-web flows. The latter analyses are also required for the essential step of determining the extent to which fishes, native or nonnative, are food limited. The results of such analyses are forthcoming and together with those presented here will provide an ecosystem-level assessment of this experiment and management actions conducted by the Glen Canyon Dam Adaptive Management Program.

\section{References Cited}

Allan, J.D., 1978, Trout predation and the size composition of stream drift: Limnology and

Oceanography, v. 23, p. 1231-1237. 
Allan, J.D., and Castillo, M.M., 2007, Stream ecology: structure and function of running waters, 2nd ed.: Springer.

Alonso, A., and Castro-Diez P., 2008, What explains the invading success of the aquatic mud snail Potamopyrgus antipodarum (Hydrobiidae, Mollusca)?: Hydrobiologia, v. 614, p. 107-116.

Armitage, P.D., 1976, A quantitative study of the invertebrate fauna of the River Tees below Cow Green Reservoir: Freshwater Biology, v. 6, p. 229-240.

Benke, A.C., and Wallace, B.J., 1980, Trophic basis of production among net-spinning caddisflies in a southern Appalachian stream: Ecology, v. 61, p. 108-118.

Benke, A.C., 1990, A perspective on America's vanishing streams: Journal of the North American Benthological Society, v. 9, p. 77-88.

Benke, A.C., 1993, Baldi Memorial Lecture: Concepts and patterns of invertebrate production in running waters: Verhandlungen der Internationalen Vereinigung für theoretische und angewandte Limnologie, v .25, p. 15-38.

Benke, A.C., Huryn, A.D., Smock, L.A., and Wallace, J.B., 1999, Length-mass relationships for freshwater macroinvertebrates in North America with particular reference to the southeastern United States: Journal of the North American Benthological Society, v. 18, p. 308-343.

Benke, A.C., and Huryn, A.D., 2006, Secondary productivity of macroinvertebrates, in Hauer, F.R., and Lamberti, G.A., eds., Methods in stream ecology: Elsevier, New York, N.Y., p. 691-710.

Blinn, D.W., and Cole., G.A., 1991, Algal and invertebrate biota in the Colorado River: comparison of pre-and post-dam conditions, in Colorado River ecology and dam management: National Academy Press, Washington, D.C., p.102-123.

Bunn, S.E., and Arthington, A.H., 2002, Basic Principles and Ecological Consequences of Altered Flow Regimes for Aquatic Biodiversity: Environmental Management, v. 30, p. 492-507.

Carothers, S.W., and Brown, B.T., 1991, The Colorado River through Grand Canyon; natural history and human change: The University of Arizona Press, Tucson, Ariz.

Childs, M.R., Clakson, R.W., and Robinson, A.T., 1998, Resource use by larval and early juvenile native fishes in the Little Colorado River, Grand Canyon, Arizona: Transactions of the American Fisheries Society, v. 127, p. 620-629.

Cross, W.F., Rosi-Marshall, E.J., Behn, K.E., Kennedy, T.A., Hall, R.O., Fuller, A.E., and Baxter, C.V., in press, Invasion and production of New Zealand mud snails in the Colorado River, Glen Canyon: Biological Invasions.

Edmunds, G.F., Jr., 1959, The mayflies of Glen Canyon Dam area, Colorado River, Utah: Utah Academy Proceedings, v. 36, p. 79-80.

Haden, G.A., Shannon, J.P., Wilson, K.P., and Blinn, D.W., 2003, Benthic community structure of the Green and Colorado Rivers through Canyonlands National Park, Utah, USA: Southwestern Naturalist, v. 48, p. 23-35.

Hall, R.O., Wallace, J.B., and Eggert, S.L., 2000, Organic matter flow in stream food webs with reduced detrital resource base: Ecology, v. 8, p. 3445-3463.

Hall, R.O., Dybdahl, M.F., and VanderLoop, M.C., 2006, Extremely high secondary production of introduced snails in rivers: Ecological Applications, v. 16, p. 1121-1131.

Howard, A., and Dolan, R., 1981, Geomorphology of the Colorado River in the Grand Canyon: Journal of Geology, v. 89, p. 269-298.

Huryn, A.D., 1996, An appraisal of the Allen paradox in a New Zealand trout stream: Limnology and Oceanography, v. 41, p. 243-252. 
Konrad, C.P., Brasher, A.M.D., and May, J.T., 2008, Assessing streamflow characteristics as limiting factors on benthic invertebrate assemblages in streams across the western United States: Freshwater Biology, v. 53, p. 1983-1998.

Korman, J., Kapliniski, M., and Melis, T.S., 2010, Effects of high-flow experiments from Glen Canyon Dam on abundance, growth, and survival rates of early life stages of rainbow trout in the Lees Ferry reach of the Colorado River: U.S. Geological Survey Open-File Report 2010-1034, 31 p..

Ligon, F.K., Dietrich, W.E., and Trush, W.J., 1995, Downstream ecological effects of dams: BioScience, v. 45, p. 183-192.

Loo, S.E., Nally, R.M., and Lake, P.S., 2007, Forecasting New Zealand mudsnail invasion range; model comparisons using native and invaded ranges: Ecological Applications, v. 17, p. 181-189.

McKinney, T., Ayers, A.D., and Rogers, R.S., 1999, Macroinvertebrate drift in the tailwater of a regulated river below Glen Canyon Dam: Southwestern Naturalist, v. 44, p. 205-210.

Merritt, R.W., Cummins, K.W., and Berg, M.B., 2008, An introduction to the aquatic insects of North America, 4th ed.: Kendall/Hunt Publishing Co., Dubuque, Iowa.

Minckley, W.L., Marsh, P.C., Deacon, J.E., Dowling, T.E., Hedrick, P.W., Matthews, W.J., and Mueller, G., 2003, A conservation plan for native fishes of the Lower Colorado River: BioScience, $v$. 53, p. 219-234.

Morin A., Mousseau, T.A., and Roff, D.A., 1987, Accuracy and precision of secondary production estimates: Limnology and Oceanography, v. 32, p. 1342-1352.

Musser, G.G., 1959, Annotated check list of aquatic insects of Glen Canyon, in Ecological studies of the flora and fauna in Glen Canyon: University of Utah Anthropological Papers, Salt Lake City, p. 207211.

Nilsson, C., Reidy, C.A., Dynesius, M., and Revenga, C., 2005, Fragmentation and flow regulation of the world's large river systems: Science, v. 308, p. 405-408.

Patten, D.T., Harpman, D.A., Voita, M.I., Randle, T.J., 2001, A managed flood on the Colorado River: background, objectives, design, and implementation: Ecological Applications, v. 11, p. 635-643.

Poff, N.L., and Allan, J.D. 1995. Functional organization of stream fish assemblages in relation to hydrological variability: Ecology, v. 76, p. 606-627.

Poff, N.L., Allan, J.D., Bain, M.B., Karr, J.R., Prestegaard, K.L., Richter, B., Sparks, R., and Stromberg, J., 1997, The natural flow regime: a new paradigm for riverine conservation and restoration: BioScience, v. 47, p. 769-784.

Poff, N.L., Olden, J.D., Merritt, D., and Pepin, D., 2007, Homogenization of regional river dynamics by dams and global biodiversity implications: Proceedings of the National Academy of Sciences, v. 104, p. 5732-5737.

Pringle, C.M., Freeman, M., and Freeman, B., 2000, Regional effects of hydrologic alterations on riverine macrobioita in the New World; tropical-temperate comparisons: BioScience, v. 50, p. 807823.

Richter, B.D., Warner, A.T., Meyer, J.L., and Lutz, K., 2006, A collaborative and adaptive process for developing environmental flow recommendations: River Research and Applications, v. 22, p. 297318.

Robinson, C.T., Uehlinger, U., and Monaghan, M.T., 2004, Stream ecosystem response to multiple experimental floods from a reservoir: River Research and Applications, v. 20, p. 359-377.

Robinson, C.T., and Uehlinger, U., 2008, Experimental floods can cause ecosystem regime shift in a regulated river: Ecological Applications, v. 18, p. 511-526.

Rosi-Marshall, E.J., and Wallace, B.J., 2002, Invertebrate food webs along a stream resource gradient: Freshwater Biology, v. 47, p. 129-141. 
Schmidt, J.C., Parnell, R.A., Grams, P.E., Hazel, J.E., Kaplinski, M.A., Stevens, L.E., and Hoffnagle, T.L., 2001, The 1996 controlled flood in Grand Canyon: flow, sediment transport, and geomorphic change: Ecological Applications, v. 11, p. 657-671.

Shafroth, P.B., Wilcox, A.C., Lytle, D.A., Hickey, J.T., Andersen, D.C., Beauchamp, V.B., Hautzinger, A., McMullen, L.E., and Warner, A., 2009, Ecosystem effects of environmental flows: modeling and experimental floods in a dry land river: Freshwater Biology, v. 55, p. 68-85.

Shannon, J.P., Blinn, D.W., McKinney, T., Benenati, E.P., Wilson, K.P., O’Brien, C., 2001, Aquatic food base response to the 1996 test flood below Glen Canyon Dam, Colorado, River, Arizona: Ecological Applications, v. 11, p. 672-685.

Stehr, F.W., 1987, Immature insects, vol. 1: Kendall/ Hunt Publishing, Dubuque, Iowa.

Stevens, L.E., Shannon, J.P., and Blinn, D.W., 1997, Colorado River benthic ecology in Grand Canyon, Arizona, USA; dam, tributary and geomorphological influences: Regulated Rivers: Research and Management, v. 13, p. 129-149.

Topping, D.J., Schmidt, J.C., and Vierra, L.E., Jr., 2003, Computation and analysis of the instantaneous-discharge record for the Colorado River at Lees Ferry, Arizona-May 8, 1921, through September 30, 2000: U.S. Geological Survey Professional Paper 1677.

Vinson, M.R., 2001, Long-term dynamics of an invertebrate assemblage downstream from a large dam: Ecological Applications, v. 11, p. 711-730.

Vinson, M.R., and Baker, M.A., 2008, Poor growth of rainbow trout fed New Zealand mud snails Potamopyrgus antipodarum: North American Journal of Fisheries Management, v. 28, p. 701-709.

Walters, C.J., and Holling, C.S., 1990, Large-scale management experiments and learning by doing: Ecology, v. 71, p. 2060-2068.

Ward, J.V., and Stanford, J.A., 1983, The serial discontinuity concept of lotic ecosystems, in Fontaine, T.D., and Bartell, S.M., eds., Dynamics of lotic ecosystems: Ann Arbor Science Publications, Ann Arbor, MI, p. 29-42.

Williams, R.N., 2006, Return to the river: restoring salmon to the Columbia River: Elsevier Academic Press, San Diego, California.

Wright, S.A., Anderson, C.R., and Voichick, N., 2009, A simplified water temperature model for the Colorado River below Glen Canyon Dam: River Research and Application, v. 25, p. 675-686. 
This page intentionally left blank 


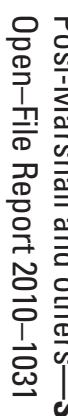

함

䒠

罾

$\stackrel{\circ}{\bar{z}}$

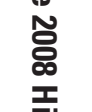

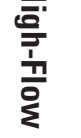

蓄

ㄱ.ᅳㄹ.

$\stackrel{\mathrm{g}}{\mathrm{g}}$

0
$\mathbf{3}$
$\mathbf{3}$
$\mathbf{3}$

을.

\$્

훌

क

ت'

응

흥

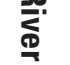

品

몸

$\stackrel{9}{=}$

옳

잉

ڤั

ㄱ.

을

| 